ACCEPTED VERSION BEFORE PROOF CORRECTIONS. Full version at https://jgs.lyellcollection.org/ content/early/2019/06/04/jgs2018-093

\title{
The Mesoproterozoic Stac Fada proximal ejecta blanket, NW Scotland: constraints on crater location from field observations, anisotropy of magnetic susceptibility, petrography, and geochemistry
}

\author{
Kenneth Amor ${ }^{1 *}$, Stephen P. Hesselbo ${ }^{2}$, Don Porcelli ${ }^{1}$, Adam Price ${ }^{1}$, Naomi Saunders ${ }^{1}$, \\ Martin Sykes ${ }^{1}$, Jennifer Stevanovic ${ }^{1} \&$ Conal MacNiocaill ${ }^{1}$ \\ ${ }^{1}$ Department of Earth Sciences, University of Oxford, South Parks Road, Oxford OX1 3AN, \\ $U K$ \\ ${ }^{2}$ Camborne School of Mines and Environment and Sustainability Institute, University of \\ Exeter, Penryn Campus, Penryn, Cornwall TR10 9FE, UK \\ *Corresponding author (e-mail: ken.amor@earth.ox.ac.uk)
}

\begin{abstract}
:
The Stac Fada Member of the Mesoproterozoic Stoer Group (Torridon Supergroup) in NW Scotland is a proximal ejecta blanket surrounding an unidentified asteroid impact crater. A combination of field observations of the ejecta deposit and underlying strata, the geographical distribution of terrane-identified basement clasts found embedded in the impactite, and anisotropy of magnetic susceptibility of the impact melt rocks at different locations, can constrain the crater location to be about 15-20 km WNW of Enard Bay and thus buried under Mesozoic sediments in The Minch. Syn-compressional structures within the suevite at Stattic Point give a clear indication of a south-easterly direction of mass motion. The signatures of two different terranes within the Lewisian gneiss help identify the origin of clasts found in the impactite at three locations. These clasts are un-shocked and interpreted as having been swept up by the density current post-impact; their geographic distribution provides an important clue to ejecta emplacement pathways crossing the Assynt and Gruinard terranes. Anisotropy of magnetic susceptibility is used to measure flow direction in pyroclastic density current deposits and is applied here to derive a direction of motion for the impactoclastic density current. It provides good agreement with the other independent methods.
\end{abstract}

The Mesoproterozoic Stac Fada Member (SFM) of the Stoer Group of NW Scotland was first described as a basal conglomerate containing clasts of mafic dyke material (Peach et al., 1907). The abundant mafic material was subsequently recognized as comprising dark green, vesicular, devitrified glass fragments, and a volcaniclastic origin for the deposit was proposed: as an ash or pyroclastic flow (Lawson, 1972); as a volcanic peperite formed by a phreatomagmatic eruption of basic magma in contact with groundwater or shallow lakes (Sanders \& Johnson, 1989); as an airfall tuff (Young, 1999, 2002), or; as volcanic mudflow (Stewart, 2002). However, Stewart (2002) also recognized that none of the proposed origins adequately explain all the observations. The identification of quartz grains with multiple sets of planar deformation features, platinum group elements in higher than normal crustal abundances and a non-terrestrial chromium isotope anomaly led to the re-interpretation of the Stac Fada Member as a proximal impact ejecta blanket beyond the margins of an as yet undiscovered meteorite impact crater (Amor et al., 2008). Consequently many of the depositional, petrographic, and geochemical features of this unit and adjacent strata took on a new significance. Although no source impact crater (or related crustal structure) has yet been identified on the Scottish mainland, the possibility remains that it has been obscured by thrust sheets of the Moine thrust belt ( $\sim 430 \mathrm{Ma}$ ) that formed during the Caledonian Orogeny in the course of the closure of the Iapetus Ocean. Recently, Simms (2015) suggested that the 
impact crater is associated with the Lairg gravity low about $50 \mathrm{~km}$ to the east of the closest outcrop of the Stac Fada Member, and based upon field evidence at Stoer. However, the evidence available hitherto is very limited in scope and considerable uncertainty remains.

It is assumed that the proximal ejecta blanket originally formed a toroidal deposit surrounding the impact crater, whose thickness decreases in all directions away from the crater, and that the present day nearly linear outcrop of the Stac Fada Member (figure 1) forms a chord through that ejecta blanket (Amor et al., 2008). If the angle of impact were very oblique ( $<30$ degrees) then a directional bias may have been introduced into the ejected material (Gault \& Wedekind, 1978). Branney \& Brown (2011), analysing the distribution of accretionary lapilli and pellets, infer that the suevitic ejecta blanket in this case was largely deposited by a stratified impactoclastic density current comprising a ground-hugging component of granular fluid passing upward into a less concentrated, turbulent and buoyant layer, and conclude that there may be several different mechanisms operating on planets with atmospheres and surface and sub-surface volatiles that may depend upon the precise nature of the target material. The high proportion of melt clasts in the Stac Fada impactite is a strong indication of high water content involved in the impact process, because impact melt is more readily formed in target rocks rich in volatiles, and is more likely to be widely dispersed from the impact site because of rapid volatile expansion (Kieffer \& Simonds, 1980). The presence of water and/or other volatiles can have a strong effect on crater and ejecta morphology via yield strength and viscosity of the ejected material. Note that we use the Stoffler and Grieve (2007) definitions for impactites and refer to either suevite or clast poor impact melt rocks, as appropriate, to describe the fabric of the Stac Fada Member.

In summary, there remain many unanswered questions with respect to both original impact location and the nature of the target rocks, which both have substantial implications for understanding of the impact emplacement processes represented by the Stac Fada Member. This paper, then, provides new observations and data that resolve several of these outstanding issues, specifically:

1) field observations on the internal organization and fabric of the deposit and underlying strata to gauge flow characteristics and direction of emplacement;

2) lithology and provenance of basement clasts embedded in the suevite and their palaeogeographic distribution to constrain the metamorphic terrane of the target rock or along the path of the ejecta ground surge;

3) anisotropy of magnetic susceptibility (AMS) of the suevite and clast poor impact melt rocks to determine direction of flow or stress (e.g. Hrouda, 1982; Rees, 1965; Ellwood, 1982).

\section{Geological Setting}

The Stoer Group is the lowermost unit of the Precambrian sedimentary sandstones often referred to as the Torridonian Supergroup. The overall palaeoenvironment is typical of semi-arid terrestrial deposition (Stewart, 2002), consistent with its palaeogeographic position on the passive margin on the southern or eastern side of the Laurentia craton (e.g. Dalziel, 2010). Estimates of palaeolatitude range from $8^{\circ}$ north (Torsvik \& Sturt, 1987), 10-1 $11^{\circ}$ north (Piper \& Poppleton 1991) and $14^{\circ}$ north (Stewart \& Irving, 1974). It is generally accepted that the Stoer Group was deposited in an extensional basin, which was either in a rift valley or half graben setting (Stewart, 2002; Kinnaird et al., 2007). The sediments infill an irregular land surface with a topographic basement relief of several hundred meters $(<300 \mathrm{~m})$ consisting of palaeo-hills, steep-sided canyons, and gullies eroded into the underlying Lewisian Gneiss. The Stoer Group comprises several sedimentary facies including a basal conglomerate overlying a weathered gneissic surface, alluvial fan deposits, and braided 
100 stream and sheet-wash units, interspersed between strata representing more quiescent lacustrine deposition (Stewart, 2002).

The Stoer Group has sustained only mild metamorphism, to prehnite-pumpellyite facies $\left(250-350^{\circ} \mathrm{C}\right)($ Stewart, 2002), and the felspathic sandstones are albitized. The strata have acquired a regional dip of about $15-20^{\circ}$ to the west, and are assumed to underlie much of the offshore Minch Basin between the Isle of Lewis and the Scottish mainland at an unknown depth. The Stac Fada Member outcrops for about $50 \mathrm{~km}$ along the NW coast of Scotland, from the Stoer Peninsula in the north to the southern side of Loch Ewe in the south, where it outcrops in stream sections (Stewart 2002). Both the northernmost and southernmost outcrops are truncated by faults, and the Coigach Fault truncates the Stoer Group to the west of the surface outcrop (figure 1) and has an unknown throw. The fault may have been active at the time of deposition (Stewart, 1993). The age of the Stac Fada Member has been estimated at $1177 \pm 5 \mathrm{Ma}$ based on Ar-Ar ages of authigenic potassium feldspars precipitated in hydrothermal veins within the Stac Fada Member (Parnell et al., 2011).

The Stoer Group is underlain by Archaean-Palaeoproterozoic basement comprising the Lewisian gneiss Complex which is thought to underlie much of North West Scotland. Geophysical evidence suggests that Lewisian type basement extends from outcrop in NW Scotland to the Great Glen Fault i.e. underlying the overthrust Moine metasediments (e.g. Bastow et al., 2007). Furthermore, gneiss inliers within the Moinian rocks bear a striking petrographic and geochemical resemblance to Lewisian gneiss (Strachan and Holdsworth, 1988 and refs therein). This Hebridean Terrane has been subjected to distinct metamorphic events: the Scourian Complex metamorphosed to granulite facies during the Badcallian Event $(\sim 2500 \mathrm{Ma})$, the Inverian tectonic activity and uplift with retrograde metamorphism to amphibolite facies ( 2490-2400 Ma) and the Laxfordian ( 1860-1630 Ma) (Park et al., 2002). The Lewisian Complex is thought to consist of several discrete Archaean terranes that became amalgamated during the Palaeoproterozoic, rather than being constructed from one contiguous piece of crust (Friend \& Kinny, 2001; Kinny et al., 2005) (figure 1), and it cannot be assumed that the age of these metamorphic events is the same across all Lewisian Gneiss terranes (Park et al., 2002).

\section{Field observations}

The principal outcrops of the Stac Fada Member, running north to south, are at Stoer Peninsula (by Stac Gruin), Rubh' a' Choin at Enard Bay, Achiltibuie (not sampled), Cailleach Head (not sampled), Stattic Point, Second Coast on the south side of Gruinard Bay, Rubha' Aird na Ba (on the southern side of Loch Thurnaig) near Poolewe and Bac an Leth Choin on the south-western side of Loch Ewe (Figure 1).

\section{Stoer Peninsula (Stac Gruin) [grid ref. NC 033285]}

The Stac Fada Member at Stoer is approximately $11 \mathrm{~m}$ thick and has large (up to $10 \mathrm{~m}$ long), deformed tabular rafts of locally derived sandstone in the lowest 4 metres as described by Stewart (2002) (figure 2a). All the detached sandstone slabs are completely enveloped by impact melt rocks. We attribute this to the delamination decoupling and tensile break-off of the bedded sandstone units caused by a combination of impact-induced ground shaking, weak spallation resulting from the interference of shock and release waves, and surface dragging imparted by the arrival of the rapid, outward moving ejecta curtain (Kenkmann and Schonian, 2006) or particulate density current using the model of Branney and Brown (2011). Such deformation is predicted by Kenkmann \& Ivanov (2006) to occur within 1.8 crater radii around craters in layered targets. If the impact crater lies at our suggested location to the southwest of Stoer (see discussion below) and is in the range of $15-20 \mathrm{~km}$ in diameter then Stoer is just on the outer limit where such deformation is expected. A small decimetre-scale 
150 buckle fold occurs in the sandstone immediately beneath the SFM (figure $2 \mathrm{~d}$ and stereonet figure 10f). The trend and plunge of the hinge line is $073^{\circ} / 15^{\circ} \mathrm{W}$ indicating compressional melt-rich breccia injected between bedding planes of the underlying sandstones for up to $5 \mathrm{~m}$ and which pinches out towards the NE (figures $2 b, 2 c$ ). Further to the south at this outcrop this same melt rich breccia can be seen to pinch and swell (Simms, 2015 figure 5). A large block of detached sandstone has bedding overturned with its fold axis in a SE-NW orientation (figure 2e). There are no way-up criteria in the sandstone, but the bedding planes trace a recumbent fold.

Accretionary lapilli (maximum diameter $=7.1 \mathrm{~mm}$; mean diameter $=2.9 \mathrm{~mm} ; \mathrm{n}=54$ ) appear from $\sim 8 \mathrm{~m}$ above the base, where they occur sporadically in concentrated pockets, in contrast to the continuous beds observed at Enard Bay. The lapilli at Stoer are flattened vertically as compared to their counterparts at Enard Bay, and appear ellipsoidal with their equal long horizontal axes parallel to bedding and are assumed to have been squashed either during landing or subsequent deposition and settling of the density current. Very few of the lapilli are broken and therefore it is assumed they were deposited in the density current when this had reached relatively low velocities. The lapilli are commonly surrounded by an outer sheath of feldspar, thought to be of vapor phase, sublimate origin and contemporaneous with deposition (Lawson, 1972; Branney \& Brown, 2011). This does not appear cracked or fractured and suggest post-depositional compaction was minimal.

\section{Enard Bay (Camas a' Bhothain) [grid ref. NC 026147]}

Towards the base of the Stac Fada Member at Enard Bay is a 0.5-1 m thick, blocky, breccia layer composed of rounded, angular and tabular, gneissic fragments up to $0.5 \mathrm{~m}$ in diameter, surrounded by a sandstone matrix (figure 3a). In the uppermost layer of the breccia bed metre-scale, interlocking 'pillows' can be observed in some parts of the outcrop (figure 3b). In plan view, these 'pillows' are rounded, $1.5-2 \mathrm{~m}$ in diameter and $25 \mathrm{~cm}$ thick, and the lower surface of each 'pillow' is moulded onto the underlying substrate (figure. $3 \mathrm{~b}$ ) as a distinct unit rather than merely a weathering phenomenon, and suggesting the material behaved as a viscous fluid. They are composed of breccia fragments and a finer grained matrix. Mixing between the suevite and breccia matrix is observed, e.g. to the right of the 'pillow' in figure 3b, which is both clast and melt rich. This relationship is consistent with the surface having been pelted with ballistic lithic fragments ejected by the impact, an interpretation shared by Simms (2015), followed by the arrival of the granular density current into which fell discrete collections of lithic fragments. The absence of this breccia bed at other Stac Fada Member outcrops suggests Enard Bay may be at the outer limit of the rapidly collapsing ejecta curtain in the model of Branney and Brown (2011). The majority of clasts sampled at this location were taken from the basal breccia, since the main body of the impactite is largely devoid of lithic fragments. The breccia rests on well-bedded Stoer Group sandstone, which is never very thick at this location, as noted by Stewart (2002), presumably because the area formed on palaeotopographically higher ground than in the sedimentary basins to the north and south. Consequently, it is possible that the breccia layer is simply related to the unconformity with the Lewisian, although in counterargument such narrow bands of breccia are not observed elsewhere in the succession at this locality. Accretionary lapilli (maximum diameter $=12.0 \mathrm{~mm}$, mean diameter $=3.7 \mathrm{~mm} ; \mathrm{n}=59$ ) are found in abundance from $17 \mathrm{~m}$ above the base, and the top of the Stac Fada Member is marked by a 10 $\mathrm{cm}$ thick undulating and indurated medium grained sandstone, the ash-pellet-rich layer described and interpreted as an airfall deposit (Branney \& Brown, 2011).

For several metres above the Stac Fada Member the strata consist of fining upward beds, 5-10 cm thick, composed of coarse to very fine grained, laminated, sandstone, implying 
that post-impact sedimentation occurred in a standing body of water (figure 3c). A square cut channel with a flow direction of $6^{\circ}$ north is incised into these graded sandstone beds and is infilled by medium grained sandstone (figure $3 \mathrm{~d}$ ). This could either represent a flow direction off a speculative crater rim to the north.

\section{Stattic Point [grid ref. NG 972959 and NG966949]}

At Stattic Point (figure 4a) the Stac Fada Member is approximately $8 \mathrm{~m}$ thick and has both the highest density of melt clasts and the largest examples (17 $\mathrm{cm}$ across) known from the Stac Fada Member (figure 4b). These large 'bombs' are flattened and dish shaped and similar to those described by Hörz (1965) in the suevite at the Ries impact crater.

The clast poor, impact melt rocks at Stattic Point have a distinctive arrangement of joints that we interpret to result from compressional deformation. In profile, two shallowangle thrust faults or detachments effect small $(<1 \mathrm{~m})$ offsets in the Stac Fada Member, and are not present in the underlying sandstone (figures $5 \mathrm{a}$ and $5 \mathrm{~b}$ ). No slickenlines were observed on the exposed fault surfaces but these are now subject to wave erosion. Several smaller, stacked decollements in the impactite appear to indicate movement on internal shear planes that dip towards the north and occur on the hanging wall of the main thrust fault (figure 5) and imparting a similar sense of compressional motion as the thrust fault. The strike and dip of the two thrust faults are $\sim 081^{\circ} / 59^{\circ}$ and $\sim 071^{\circ} / 56^{\circ}$ (stereonet figure $12 \mathrm{~g}$ ). A small normal fault has a strike and dip of $076^{\circ} / 69^{\circ}$ (stereonet figure $12 \mathrm{~g}$ ). Small, metre-scale folds whose upturned layers are truncated on their upper surfaces occur in the upper part of the suevite. These folds are marked by fractures in the impact melt rocks on the footwall of the thrust and are interpreted as thrust fault related folding (figures $5 \mathrm{a}$ and $5 \mathrm{~b}$ ). No accurate fold axis orientation was obtainable safely but it was estimated to be approximately parallel to the thrust fault (strike $081^{\circ}$ ). To the north of the thrust fault lie the surface described by Simms (2015) as ogive curved, pressure ridges but the shape of the fractures is a more complex ogee as illustrated in figure $4 \mathrm{c}$. This ogee shape appears to have been propagated by shearing along the strike of the thrust faults and is consistent with post emplacement slumping, perhaps resulting from deposition of the impactite on a westward facing slope. Outcrops of gneiss can be found to the east of this locality and we assume higher ground existed at the time of deposition of the Stac Fada Member. The top of the member is marked by an undulating $10 \mathrm{~cm}$ thick, massive, fine to medium grained sandstone similar to an ashrich layer observed at Enard Bay (Branney \& Brown, 2011). Locally, the overlying strata are seen to truncate the folds within the Stac Fada Member and tightly constrain the relative age of the deformation.

The strata immediately underlying the Stac Fada Member are of particular interest and have small $10 \mathrm{~cm}$ high escarpments with a scarp-to-scarp distance varying between 1 to $5 \mathrm{~m}$ that occur in the upper layers of the sandstone immediately beneath the impact melt rocks (figure $4 \mathrm{~d}$ and $4 \mathrm{e}$ ). The ridge crests of the escarpments are sinuous and commonly brecciated on a millimetric scale, to a depth of between 5-30 mm, with the surface broken up into small platelets (figure $4 \mathrm{~d}$ and $4 \mathrm{e}$ ). Although much of the contact between the Clactholl Formation and the impactite is hidden beneath beach cobbles, a few wave washed, sandstone ridges can be traced beneath the impact melt rocks (figure $4 \mathrm{f}$ ). This brecciation has been formed in situ with no obvious transport of fragments and is proposed as a seismite generated by the shock wave. Alternatively the fracturing may have been caused by the rapid loading of material deposited by the impactoclastic density current. However, the brecciation is only found close to the sandstone ridges and is assumed to be associated with their formation. The average strike of the ridge crests is $065^{\circ}$ (with a range of $059-072^{\circ}$, stereonet figure $12 \mathrm{~h}$ ) implying an approximate north-south compressional direction and similar to the strike of the small thrust 
faults described above. The Stac Fada Member makes a sharp contact with the underlying sandstone and the matrix of the lowest $20 \mathrm{~cm}$ of the impact melt rocks is very fine grained, with melt clasts almost completely absent. In the level above $20 \mathrm{~cm}$ and up to about $1 \mathrm{~m}$ above the base, the longer axes of the melt clasts are aligned weakly parallel to the lower boundary when viewed in cross-section (figure $4 \mathrm{~g}$ ).

\section{Second Coast [grid ref. NG 926 911]}

At Second Coast on the southern side of Gruinard Bay, the Stac Fada clast poor, impact melt rock is underlain for about $1 \mathrm{~m}$ by a massive, medium to coarse grained, moderately to poorly sorted sandstone with some faint cross-bedding. The striking feature of this sandstone is the large, $0.5 \mathrm{~m}$ diameter gneiss blocks, previously described by Stewart (2002). These boulders can be found down to $2 \mathrm{~m}$ beneath the basal contact of the impact melt rocks and contain no sign of shock metamorphism. Ash aggregates in the form of pellets are present in the uppermost layers of the impactite at Second Coast in a discontinuous band about $0.5 \mathrm{~m}$ thick (figure $6 \mathrm{a}$ ). Ash pellets have not previously been described from this location and are about 4-5 $\mathrm{mm}$ across their long axes and have the appearance of small brown lentils. Although no thin sections were made from samples at Second Coast, outwardly they appear similar to the ash pellets found at Enard Bay (figure 6b). Adopting the nomenclature of Brown et al., (2010), the ash aggregates at Enard Bay occur as coated pellets and cored pellets, and have poorly sorted cores, ranging in grain size from very fine ash to very coarse sand. The ash pellets at Second Coast have an outer coating of fine-grained material.

\section{Loch Thurnaig [grid ref. NG 862834 ]}

The Stac Fada Member is only 5-6 m thick at Loch Thurnaig. The melt clasts here are typically small $(0.5 \mathrm{~mm})$ and randomly orientated. Where the sandstone bed immediately beneath the suevite is exposed, shallow, parallel striations can be seen with north-south orientations of $166-179^{\circ}$ and is of particular note (stereonet figure 13d). It is assumed they were formed by clastic material being dragged along the sandstone surface by the density current.

\section{Bac an Leth Choin [grid ref. NG 774 893]}

At Bac an Leth Choin, the Stoer Group and Stac Fada Member are offset from the Loch Thurnaig outcrop by the NW-SE trending Loch Maree fault, and the strike distance is only about $2-3 \mathrm{~km}$. The Stac Fada Member is poorly exposed in stream sections at this location. The base can be made out in a small plunge pool while the top is hidden beneath post-glacial peat cover. It is notable here that the thickness of the Stac Fada Member is apparently greater than $30 \mathrm{~m}$, and so is the thickest documented deposit. In appearance the abundant green, devitrified melt clasts are very flattened, typically $5 \mathrm{~mm}$ wide, occasionally $1.5-2 \mathrm{~mm}$ and $0.5-0.75 \mathrm{~mm}$ thick. Almost all the melt clasts have their equiaxed flattened surface aligned parallel to the base of the member, as seen in cross section.

\section{Lithic Clast Provenance}

On the mainland, Kinny et al., (2005) have identified six metamorphic terranes within the Lewisian gneiss that they interpret as distinct tectonic micro-cratons, each distinguished by composition, mineralogy, age, and metamorphic grade (Figure 1). The three metamorphic terranes lying closest to the present-day outcrop of the Stac Fada Member are from north to south, the Rhiconich Terrane (also called Northern and Laxfordian Terrane), the Assynt Terrane (otherwise known as the Central and Scourian Terrane) and the Gruinard Terrane. 
The Rhiconich Terrane forms a basement complex to the west of the Moine Thrust amphibolite facies in an event dated $\sim 1740 \mathrm{Ma}$ (Kinny et al., 2005). The Assynt Terrane stretches from the Strathan Line north to the Laxford Front at Loch Laxford. These rocks were metamorphosed to granulite facies in the Badcallian Event at $\sim 2480 \mathrm{Ma}$ (Friend \& Kinny, 1995). In the south of the relevant area, the Gruinard Terrane (once thought to be part of the Scourian) forms the basement rocks from the Shieldaig shear zone to the Strathan Line. These rocks have also been metamorphosed to granulite facies dated $2730 \mathrm{Ma}$ (Love et al., 2004). It is thought that these terrane boundaries extend linearly, south-eastwards beneath the Moine over-thrust metasediments as far as the Great Glen Fault, as indicated by geophysical data (Bastow et al., 2007) and petrographic, structural and geochemical data (Strachan and Holdsworth, 1988).

Selected lithic clasts (>10 mm diameter) were chiselled out predominantly from the matrix of the Stac Fada Member suevite. A total of 31 metamorphic clasts were collected from Stoer (15), Enard Bay (13) and Static Point (3). Three of these clasts were found in an incised channel in post-impact sediments above the lapillite at Enard Bay. Additionally, two matrix samples with substantial amounts of authigenic feldspar were obtained. Thin sections were prepared from each sample and the Lewisian gneiss clasts systematically searched for signs of shock metamorphism but neither shocked quartz grains nor kinked sheet silicates were found. Each clast was also assessed for signs of alteration by weathering and some kaolinization and epidotization of feldspars was evident and is ubiquitous in the Lewisian gneiss.

At Stoer the mineralogy of the gneiss clasts is dominated by quartz and microcline, with accessory plagioclase and potassium-feldspar. The microcline forms medium-coarse grained porphyroblasts that are commonly cut by hematite-filled micro-cracks. Pyroxene grains are present in a few of the thin sections, indicating granulite facies metamorphism (Winter, 2001). Some of the pyroxene grains display zoning, indicating net-transfer reactions in a retrograde process following peak metamorphic conditions (Miyashiro, 1994). The minerals show replacement textures such as reaction rims, mineral inclusions and breakdown of porphyroblasts to quartz, epidote, chlorite and micas, indicative of a second, metamorphic event to greenschist-amphibolite facies. Unlike the case at Enard Bay, these replacement textures preserve relics of the peak metamorphic assemblage.

The gneiss clasts at Enard Bay are typically composed of quartz and plagioclase which make up 80-90\% of the rock. Plagioclase is mostly present as porphyroblasts, averaging $0.5-2.0 \mathrm{~mm}$ in diameter, while quartz is present as both porphyroblasts and groundmass. Textural equilibrium is good in the coarser fraction, but poor in the groundmass. The groundmass shows a replacement texture occupying veins, vugs and grain-shaped zones $0.5-2.0 \mathrm{~mm}$ in diameter, and composed of chlorite, epidote, micas, and hematite, which in places infiltrate the quartz and plagioclase porphyroblasts. Chlorite is present as elongate laths up to $1 \mathrm{~mm}$ in length, and gives the rock a weak schistosity. Epidote occupies similar zones as the chlorite, occurring in large clusters. Biotite and muscovite exist as minor phases typically comprising $<5 \%$ of the mineral constituents. Compositional banding is expressed by the distribution of porphyroblasts, and some samples show a weak segregation between quartz and plagioclase. Micro-cracks (typically $<0.02 \mathrm{~mm}$ across) are common in many of the porphyroblasts and are infilled by radiating masses of hematite or authigenic feldspar.

The primary mineralogy of the rocks, quartz and plagioclase, suggest an originally granulite facies, attained at peak metamorphism, that has undergone a second phase of metamorphism to greenschist or amphibolite grade. We infer that the pyroxenes have been replaced by quartz, chlorite, epidote and other accessory minerals, which cluster in discrete groups. This is consistent with observations that the Assynt and Gruinard Terrane rocks are 
polymetamorphic (Corfu et al., 1994; Kinny et al., 2005; Love et al., 2004; and Whitehouse et al., 1996) and U-Pb zircon data of the Gruinard Terrane found multiple stages of metamorphic recrystallization, giving a protolith age of $2825 \pm 8 \mathrm{Ma}$ and a metamorphic age of $2733 \pm 12 \mathrm{Ma}$ (Love et al., 2004). The petrology of the Gruinard Terrane indicates a although the timing is poorly constrained (Kinny et al., 2005). The evolution of the Assynt Terrane is better understood, with protolith ages of $\sim 3030-2960 \mathrm{Ma}$ and granulite facies metamorphism in the Badcallian Event at $2490-2480 \mathrm{Ma}$ (Friend \& Kinny, 1995). The main retrogression event occurred during the Laxfordian metamorphism at 1740 Ma (Kinny et al., 2005).

The metamorphic clasts (EB153B, EB158B) collected from the incised channel infill a few metres above the top of the ejecta deposit are mineralogically similar to the other metamorphic clasts collected at Enard Bay, displaying a granulite facies assemblage and texture, overprinted with greenschist to amphibolite facies minerals, and may be derived from locally reworked material. Sample EB216 collected from the same channel is more felsic and $65-70 \%$ of the rock is composed of plagioclase that displays micro-folding and faulting. The microstructures present in the plagioclase are unique for the clasts sampled and suggest that EB216 has undergone a type of deformation not experienced by the other gneiss clasts.

The Stattic Point gneiss clasts are similar in appearance to those collected from Stoer, being composed of quartz, microcline and plagioclase with the same greenschist-amphibolite facies replacement minerals.

Petrological evidence suggests that the gneiss clasts from all locations were sourced from a granulite facies terrane that had retrogressed to an amphibolite facies, i.e. either the Gruinard or Assynt terrane.

\section{Major and Trace Element Geochemistry}

For the geochemical analysis, about $5 \mathrm{~g}$ of each sample was powdered, and $100 \mathrm{mg}$ aliquots digested with $\mathrm{HF}$ and $\mathrm{HNO}_{3}$. Analysis of major and trace element abundances were made using a Thermo Finnigan Element 2 single collector, inductively coupled plasma mass spectrometer (ICP-MS) at Oxford University. The instrument was calibrated using single and multi-element calibration standards supplied by CPAChem Ltd. For elements with $\mathrm{mg} / \mathrm{kg}$ values $>1$, the internal error is $1-2 \%$ and external error $5 \%$. All acid used was purified by subboiling distillation in quartz stills and diluted with ultra-pure water produced from an Elga water purification system to 18 -M $\Omega$ grade. PerFluoroAlkoxy (PFA) Teflon vials supplied by Savillex of various capacities were used exclusively for sample dissolution, collection and evaporation. Procedural blanks for all elements were negligible.

Whole rock abundances for the major and selected trace elements are presented in Tables 1a and 1b. Duplicate samples showed good reproducibility for all elements, with the exception of zinc, and all samples have a systematic depletion in $\mathrm{Hf}$ and $\mathrm{Zr}$, thought to be due to incomplete zircon dissolution. Amphibolite and granulite facies may be distinguished geochemically by the normalized abundances of the large ion lithophile elements ( $\mathrm{Rb}, \mathrm{K}, \mathrm{U}$, Th and Cs), with granulite facies rocks having depletions in these elements, thought to have occurred by fluid phase flushing during metamorphism (Corfu et al., 1994; Drury, 1978; Fowler, 1986; Rollinson \& Windley, 1980; Weaver \& Tarney, 1980; Weaver \& Tarney, 1981; Weaver \& Tarney, 1983). Comparison of $\mathrm{Rb}$ and $\mathrm{K}$ abundance data has also been used to distinguish between the Gruinard and Assynt granulite terranes (Fowler, 1986 and Rollinson \& Windley, 1980). Although both potassium and rubidium may be leached from minerals such as biotite and K-feldspar by aqueous solutions, Nesbitt et al., (1980) found this to be marginal during early stages of continental weathering. 
The majority of samples collected from Enard Bay and Stattic Point have trace

\section{Impactite magnetic characteristics}

When used with other geological evidence Anisotropy of magnetic susceptibility studies have successfully inferred flow directions from pyroclastic deposits e.g. Cagnoli \& Tarling 1997. A previous AMS study of the Stoer Group sediments concluded that the Stac Fada Member has a stronger magnetic anisotropy than the surrounding sediments (Darabi \& Piper, 2004).

Twenty blocks of clast poor, impact melt rocks were collected from Stoer, Enard Bay, Stattic Point and Second Coast. The orientation of a prominent plane on the sample block and the strike and dip of adjacent sandstone beds were measured in the field. A total of 115 cores with a 1 inch diameter were cut perpendicular to the prominent plane. The AMS was determined using a low-field KLY-2 Kappabridge and the data analysed using Anisoft 4.2 software. Frequency dependence of susceptibility was measured using a Bartington Instruments dual frequency magnetic susceptibility sensor, at a low and high frequency of $0.465 \mathrm{kHz}$ and $4.65 \mathrm{kHz}$, respectively.

Curie temperature analysis of ground rock samples heated to $700^{\circ} \mathrm{C}$ reveal the presence of magnetite, maghemite and haematite as carriers of the magnetic phase and concur with previous analyses by Darabi \& Piper (2004), using a similar method and instruments, that magnetite is always present. A systematic search of thin sections using SEM and energydispersive spectra also revealed two distinct iron-rich phases identified as magnetite and haematite by comparison with known mineral standards, in approximately equal proportions.

Dual-frequency of susceptibility measurements show an increase in susceptibility with increasing stratigraphic height in the impact melt unit at all four locations, indicating an increasing proportion of fine-grained superparamagnetic particles such as clay minerals and iron oxide microcrystals (figure $8 \mathrm{~b}$ ). The calculated percentage frequency dependent susceptibility (figure $8 \mathrm{a}$ ) is indicative of mixed superparamagnetic and single domain particles. There are a number of possible interpretations: a) fluid turbulence in the density current supporting finer grained material, (Branney and Kokelaar, 2002), b) hindered settling and fine ash elutriation as the density current comes to a stop (Branney and Kokelaar, 2002), c) formation of vapour phase micro-crystals of iron oxide in the upper parts of the impactite once the density current had stopped (e.g. Thomas et al., 1992). 
Anisotropy of magnetic susceptibility can be used to determine the fabric of magnetic particles in rocks which may acquire a preferred orientation during transport and deposition in response to shear stress or gravitational and hydrodynamic forces acting during sedimentation, although mineral grains can also acquire a preferred direction growing under hydrostatic or tectonic stress fields at later stages of diagenesis. In undeformed sediments, the magnetic fabric can comprise two parts: firstly, a gravitationally forced magnetic foliation parallel to the bedding plane and secondly, a lineation or preferred grain orientation caused by the hydrodynamic environment (Rees \& Woodall, 1975). Anisotropy of magnetic susceptibility results are plotted on a lower hemisphere equal area projection, using a tectonic coordinate system correcting for local strike and dip of the Stoer Group strata. The results are expressed mathematically as a symmetric, second-order tensor, and represented geometrically as a triaxial ellipsoid. The principal axes are represented by the terms Kmaximum (K1), Kintermediate (K2) and Kminimum (K3) and the ellipsoid symbolizes information about the preferred alignment and magnetic fabric of ferromagnetic grains. The axial ratios may be used to describe the form of the magnetic ellipsoid. The magnetic lineation or the intensity of magnetic particles with a linear parallel orientation may be defined by $\mathrm{L}=\mathrm{K} 1 / \mathrm{K} 2$ and the foliation (planar-parallel orientation) $\mathrm{F}=\mathrm{K} 2 / \mathrm{K} 3$, while the degree of anisotropy may be defined as K1/K3. The direction of the magnetic lineation is equivalent to the maximum susceptibility and the magnetic foliation is transverse to the direction of minimum susceptibility. The sphericity of the ellipsoid may be determined by comparing the foliation and lineation. The ellipsoid is oblate (disk shaped) when F $>$ L, and prolate (rod shaped) when L > F. The Stac Fada impact melt rocks shows a predominance for oblate magnetic ellipsoids (F > L), with only two samples from the uppermost part of the impact melt rocks at Stattic Point having a prolate ellipsoid (Figure 9). All of our samples had a weak anisotropy of magnetic susceptibility ranging between $0.9-2 \%$, and similar to pyroclastic sediments and ignimbrite flows e.g. Cagnoli \& Tarling (1997). The minimal compaction of the impactite as suggested by the deformation in the accretionary lapilli is not thought to have significantly affected the orientation of the magnetic foliation and lineation. The Stoer Group has been subjected to low grade metamorphic conditions, and diagenetic and metamorphic growth of magnetite and paramagnetic clays may have contributed to some scatter observed in some of our samples. However, the strong magnetic foliations in different orientations found in other samples suggest they have not succumbed to a regional overprint.

When data are plotted for each sample, our AMS results fall into two types (figures 10, 11, 12 and 13). Type A has $\mathrm{K} 1$ and $\mathrm{K} 2$ data spread on a great circle (sometimes described as a girdle) defining a dipping or horizontal planar surface, while the $\mathrm{K} 3$ axis has tightly clustered values perpendicular to that plane and is commonly interpreted as a dominant magnetic foliation plane. In this instance we take the azimuth or declination bearing of the average K3 data using Jelinek statistics (Jelinek, 1978) as indicative of the flow direction. In ignimbrites the plunge direction of the foliation plane points towards the source and the foliation plane represents an imbrication of the magnetic particles (Knight et al., 1986). Type $\mathrm{B}$ has $\mathrm{K} 1, \mathrm{~K} 2$ and $\mathrm{K} 3$ data tightly grouped and defines a prevailing lineation. In this instance the $\mathrm{K} 1$ declination is used to impart directional information.

For both sedimentary and pyroclastic rocks it has been observed that the K1 and K3 axes may be either parallel to (Rusnak, 1957; Ellwood, 1982; Knight et al., 1986) or perpendicular to (Hrouda, 1982; Tarling \& Hrouda, 1993) the current or flow direction, i.e. the long axis of the magnetic particle aligns either parallel or transverse to the flow direction (Cagnoli \& Tarling, 1997). This is thought to be either due to the flow regime or reflect the domain state of the magnetic grains. Multi-domain magnetite particles have their maximum susceptibility parallel to the long grain axis, whereas uniaxial single domain magnetite particles have their maximum susceptibility perpendicular to the long axis (Potter \& 

scatter may be expected in the flow direction inferred from AMS data that may be due to local topography, channelization of the density current, and small metre- and decimetre-scale meandering in the flow (Palmer and MacDonald, 1999; LaBerge et al., 2009). In addition, source (Ort et al., 2015).

The majority of the five samples from Stoer are of AMS type A, and exhibit a strong transverse bimodality in their orientation (figure 10). The inferred orientation is east-west. An alternative north-south bearing is an option because of a concurrence with data from Enard Bay that converge in the vicinity of Soyea Island, Loch Inver and is also parallel to the compressional direction inferred from the buckle fold (figure 11 and 10f). However, data from Stattic Point and Second Coast does not support this and there is no report of unusual features on the coast by Loch Inver consistent with an impact crater.

The Enard Bay samples exhibit a mixture of type A and type B and show the most variation in azimuth direction but indicating an approximate east-west orientation (figure 11).

The six sample blocks from Stattic Point exhibit both strongly clustered magnetic lineation and foliation planes (figure 12). The inferred directions give a bimodal azimuth orientation approximately perpendicular to each other. Of significance is that one of these directions is within $15^{\circ}$ of the compressional vector inferred to have given rise to deformation in the impactite at this location, i.e. a NW-SE orientation (stereonet figure $12 \mathrm{~g}$ and $12 \mathrm{~h}$ ).

Of the three samples collected from Second Coast, two display strong K1 lineation (type B) where the lineation directions are perpendicular to each other, and the third has a strong magnetic foliation which is tilted almost vertically (figure 13). The axis of foliation is parallel to the magnetic lineation of the lowermost sample, and indicates a northwestsoutheast orientation of travel for the density current that deposited the clast poor, melt rocks.

The flow directions derived from $\mathrm{K} 1$ and $\mathrm{K} 3$ data or orientations perpendicular to these tracks are plotted on figure 14 where converging directions are shown. It is significant that moving through localities from north to south there is a consistent and progressive shift in direction from east-west to NW-SE.

\section{Discussion}

Regional geological evidence can be combined with local directional indicators presented here to constrain the most likely position of the impact crater. The geological setting was a rift valley on a passive margin (Stewart, 2002) with high ground to the East of the present day outcrop of the Stoer Group. This is inferred by westerly palaeocurrent directions in the Clachtoll sandstones, but with occasional reversals of sediment-transport direction as alluvial fans built out from the opposite graben wall, as implied by easterly palaeocurrent directions in the Bay of Stoer strata (Stewart, 2002). Detailed channel analysis in the underlying Stoer Group by Lelpi et al., (2016) in the vicinity of Stoer point to a dominantly westward palaeo flow direction. Structural reconstructions of the sedimentary basin based upon seismic reflection data infer a thickening of 'Torridonian' sediments to the west of the modern day outcrop, under the present day Minch basin (Stein, 1988), although this does not specifically refer to the Stoer Group. Evidence for the palaeogeography can be found in the steep sided canyons and valleys with an east-west orientation and incised into the Lewisian gneiss, but subsequently buried by Stoer Group sediments and that are now being exhumed by erosion, as found on the south side of the Bay of Stoer and at Clachtoll (David Waters pers. comm.). The dip corrected Stoer Group abuts the north and western facing slopes of palaeo-hills of Lewisian gneiss at Enard Bay and western facing slopes at Stattic Point. It is likely that these hills of basement gneiss would have protruded at a higher 
level above the SFM at the time of emplacement but have been further eroded by recent

548 glaciations. ground hugging, granular fluid based density current (Branney \& Brown, 2011) and this flow appears to have entrained clasts from the loose surface regolith into the impactite. Many of the clasts are rounded, implying an earlier transport history, presumably by rivers or alternatively by saltation and clast collision within the impactoclastic density current. Although Lelpi et al., (2016) and Stewart (2002) point to a predominantly westerly fluvial flow direction in the Stoer Group, the precise course of these rivers is uncertain. Consequently the single Assynt terrane clast found at Enard Bay is likely transported fluvially across the Assynt/Gruinard terrane boundary to a location between the impact crater and Enard Bay prior to the impact. The impactite makes a sharp contact with the underlying well-bedded sandstone, consistent with the erosion of unconsolidated and unlithified material by the passage of the ejecta flow, as observed in the Chicxulub ejecta blanket (Kenkmann \& Schönian, 2006).

Baloga (2005) notes that fluidized flow ejecta surrounding Martian impact craters are unable to surmount topographic obstacles, even those close to the crater rim, but instead flow around, or pile up in front of, the obstruction. At Stattic Point a gneiss palaeo-hill lies immediately to the east of the SFM outcrop. If the flow direction came from Lairg then the SFM outcrop would have been in a shadow zone whereas if the flow came from the NW then this location is sited in front of an obstacle. The compressional features observed in the impact melt rocks at Stattic Point are consistent with ejecta accumulating in front of an obstruction and give the clearest directional information and the low angle thrust faulting and folding suggest the ejecta material had an origin from the north-west. Such features are predicted to occur in fluidized ejecta blankets (Kenkmann \& Schönian, 2006). The grooves in the underlying sandstones at Loch Thurnaig confirm a NNW-SSE flow orientation.

Mars Orbiter Laser Altimeter (MOLA) topographic data of fluidized impact ejecta surrounding Tooting crater ( $29 \mathrm{~km}$ diameter) on Mars shows that away from the crater rim and terminal ramparts the proximal ejecta blanket is often very thin $(<20 \mathrm{~m})$ and Thermal Emission Imaging System (THEMIS) visible (VIS) images reveal an uneven hummocky or ridged surface (Mouginis-Mark \& Garbeil, 2007). Although the change in thickness of the SFM along strike (generally thicker to the north and thinner to the south) may not be indicative of crater proximity, the size and distribution of accretionary lapilli found at Enard Bay and Stoer suggest these locations were closer to the impact site. If they were formed in dilute ash plumes or phoenix plumes (Dobran et al., 1993) lofted above the low density buoyant zone atop the ground hugging impacto-clastic density current as described by Branney \& Brown (2011) then their size and subsequent fallout and deposition would be expected to decay systematically radially from their source, as more air is entrained and mixed with flow (Bursik and Woods, 1996). In addition, the variation in size of melt clasts (smaller in the south and larger in the north) is consistent with the impact site being closer to the northern outcrops. It is assumed the melt clasts were still liquid during transport and consequently more likely to be broken into smaller droplets or fragments the longer they are transported in the density current. Large bombs are only found in the more northerly outcrops and are assumed to have fallen out closer to the impact site.

The location at Stoer has suffered the most disruption to the underlying bedrock and the large (up to $10 \mathrm{~m}$ long) rafts of detached sandstone strata are surrounded by a matrix of suevite. In one instance a slab has been rolled and overturned. It is inferred that such features have been produced by a combination of surface delamination and spalling caused by the passage of the shock and release waves (Kenkmann \& Ivanov, 2006) along with erosion and ejecta dragging by the fast moving flow. In comparison, the deformation of 
underlying strata experienced elsewhere is mild, as exemplified by the surface seismite at Stattic Point. Such autoclastic brecciation is frequently associated with the liquefaction of semi-consolidated and thixotropic layers, caused by the passage of a seismic wave (Montenat, et al., 2007), or alternatively caused by rapid surface loading during emplacement of the impactite. The ridges are interpreted here as either the product of soft sediment deformation, or surface dragging caused by the passage of the ejecta curtain that has shaped the sediment into small ridge-like structures. Their orientation is similar to other compressional features at Stattic Point described above. Although speculative, the rapid increase in thickness of the SFM between the outcrop at Loch Thurnaig ( $5 \mathrm{~m}$ thick) and Bac an Leth Choin (30 m thick) is suggestive of a terminal rampart marking the limit of the continuous ejecta blanket.

Thus deformation features, observed locations of bombs and accretionary lapilli all point to an impact location towards the north of the present day outcrop. Directional data from compressional features, AMS, striations, and ejecta surface drag features suggest a location to the west, i.e. under the Minch Basin.

The origin of the boulders immediately beneath the Stac Fada Member at Second Coast is as yet unresolved. Simms (2015) interprets the boulders as spallation ejecta, launched during the early stages of the impact. However, we have found no indication of shock metamorphism (planar deformation features, planar fractures or kinked sheet silicates) in thin sections made from these clasts. Ballistic ejecta at other meteorite impact sites such as the Bunte Breccia are also devoid of shock metamorphism. While this does not rule out an impact origin it is unclear if they are related to the impact process.

Geochemical and petrographic analyses of the gneissic clasts contained within the Stac Fada clast poor, impact melt rocks provide a useful insight into transport flow lines of the ejected material. That none of the metamorphic clasts show evidence of shock metamorphism implies that this is dominantly sedimentary deposited material swept up and incorporated by the advancing ejecta curtain and impactoclastic density current. Furthermore if these clasts were spallation ejecta then one might expect them to be all of a single terrane unless the impact site occurred precisely on the terrane boundary. Both the Assynt and Gruinard granulite metamorphic terranes, which are texturally and mineralogically similar, may be distinguished by their $\mathrm{K} / \mathrm{Rb}$ ratios (Rollinson \& Windley, 1980). It should be noted that the Lewisian gneiss Complex is essentially bi-modal in composition i.e. ranging between tonalite and granulites (basic to ultra-mafic) and therefore some variations are to be expected between individual samples (Weaver \& Tarney, 1980). Our clast samples collected from Enard Bay and Stattic Point are characteristic of the Gruinard Terrane (Fowler, 1986) that contains 'rafts' of amphibolite bodies thought to be representative of the earliest component of the granulite gneiss complex (Rollinson \& Fowler, 1987). The Assynt and Gruinard metamorphic terranes are separated by the Strathan line which runs NW-SE and intersecting the coastline to the south of Loch Inver, between the Bay of Stoer and Enard Bay. The most northerly site, at Stoer, appears to contain gneiss material from both the Assynt and Gruinard terranes whereas all other southerly locations sampled have clasts that originate predominantly from the Gruinard Terrane, and strongly suggest the impact crater lies to the south of the Strathan line (figure 1 and 14).

The palaeo-magnetic AMS data from four locations provides a useful triangulation. That the AMS directional data lie within 15 degrees of the azimuth bearing inferred from the compressional deformation features at Stattic Point provides more evidence that the AMS data give directional information for the motion of travel of the density current. An impactoclastic density current traversing a subaerial landscape is likely to be subject to deflections from topographic features in addition to internal turbulence and channelization, and an outward radial flow way from the impact site is not anticipated. Nevertheless the AMS data can be used to get a general sense of the density current transport orientation. Whilst it is 
recognized that differing flow regimes can produce a magnetic lineation that can either be parallel to, or transverse to, the flow direction, a single intersecting solution can be found from the AMS traces from all four locations. This area of intersection is illustrated in figure the impact crater to be in the Minch Basin about 15-20 km WNW of Enard Bay. This location is consistent with the gneiss clast petrology and geochemistry, lying to the south of the Strathan line assuming that the terrane boundary continues linearly to the north-west from its mainland outcrop. Thus material transported to the south from the impact point to Enard Bay, Stattic Point and Second Coast was all from the Gruinard Terrane, whereas material transported to Stoer collected both Gruinard and Assynt Terrane material. An inferred NWSE lateral offset of $0.5 \mathrm{~km}$ by the Little Loch Broom fault that separates the two northern localities (Stoer and Enard Bay) from the southern sampling sites is not taken into consideration.

One can estimate the final crater diameter by making some assumptions about the likely thickness of Stoer Group sediments at the point of impact and then applying the equations from Melosh (1989) and Collins et al., (2005) that relate excavation depth to transient crater diameter and then transient crater diameter to final rim-rim crater diameter. As noted by Melosh (1989) the material ejected during impact originates from the uppermost layers only, to about one third of the transient crater depth, while the ejecta flow lines direct deeper material into the base of the crater. The Stac Fada Member is predominantly composed of pulverized red sandstone material with very few gneissic clasts indicating the impact was into an area with a significant sedimentary cover. Stewart (2002) observes a maximum thickness of Stoer Group sediments beneath the SFM of $1.5 \mathrm{~km}$ at Poolewe to the South that thins to $500 \mathrm{~m}$ at Stoer in the North. Assuming a $1 \mathrm{~km}$ thick sequence of sediments at the point of impact, and that it is only this sedimentary cover that is ejected, then a final crater diameter of approximately $13-14 \mathrm{~km}$ can be estimated, with a transient crater depth of $3 \mathrm{~km}$. A complex crater morphology is assumed. It is noteworthy that if a crater of the above dimensions were located as proposed, then our putative terminal rampart at Bac an Leth Choin lies about 6 crater radii to the south i.e. the same runout distance observed in fluidized ejecta blankets surrounding Martian impact craters. In addition, the second phase of intrusive emplacement of clastic veins into Lewisian gneiss at Clachtoll described by Beacom et al. (1999) and contemporaneous with Stoer Group sedimentation may have been induced by the strong seismic effects of the impact just $20 \mathrm{~km}$ away.

There are a number of objections to placing the impact crater coincident with the Lairg gravity low as proposed by Simms (2015). Both Stewart (2002) and Rainbird et al., 2001) conclude that the Stoer Group sediments were deposited in a local rift. That the bulk of the matrix of the Stac Fada Member appears to have been derived from Stoer Group sediments indicates that the asteroid impact must have been into this rift basin or an equivalent sedimentary basin of fluvial and lacustrine sediments. While one could propose a 'basin and range' style topography extending to the east of the present day Stoer Group outcrop, Friend et al (2003) suggest the mid to early Proterozoic age Moine metapelites, metapsammites and marble associated with inliers of basement gneiss in the neighbourhood of the Lairg gravity low (e.g. the Shin inlier), are marine in origin. Thus there is no definitive evidence for an equivalent or comparable non-marine, sedimentary basin in the vicinity of present day Lairg, although this could have been completely eroded away down to Lewisian basement. Furthermore, applying the same crater formation calculations for a $40 \mathrm{~km}$ diameter crater as suggested by Simms (2015) requires the projectile to impact a $2.6 \mathrm{~km}$ thick pile of non-marine sediments in a proposed sedimentary basin that subsequently has to be eroded to basement. With regards to the gravity low itself, were the area unaffected by younger tectonic activity then the Lairg gravity low might represent a good candidate for the crater 
and be directly comparable to the Ries impact crater. However the Moine Thrust belt, generated during the Caledonian orogeny, has effectively top sliced any pre-existing sediments and Lewisian basement.

Negative gravity anomalies are associated with impact craters because of the dynamic fragmentation of the country rock by a shock wave (Grady \& Kipp, 1980; Melosh et al., 1992), which reduces the overall density of the rock unit. However, removal of a substantial amount of the original country rock by first erosion and then Moine thrust sheets will reduce the amplitude of the gravity anomaly. Consequently no direct comparison with the Ries impact structure can be made. Assuming the basement gneiss has been transported west by thrusting for a distance of 20-30 km (Coward et al., 1980) then one might expect to find heavily fractured gneiss with pseudotachylite veins in the vicinity of Ben More Assynt. However no such observations have been reported. Consequently we accept the Leslie et al., (2010) model of thickened Moine sediments and intrusion of the Grudie granite to explain the Lairg gravity low and confer a Minch Basin location for the impact crater.

Our prediction for the impact crater location is based on a variety of geological observations and magnetic susceptibility information. This approach may serve as a model for investigating other suspected impact sites where only ejecta deposits are visible. The AMS data gives directional information co-incident with field observations and implies that the ejecta was transported as a flowing density current i.e. non-ballistic transport and deposition, and most likely mobilized by fluidized surface and ground water.

\section{References}

Allmendinger, R. W., Cardozo, N. C., and Fisher, D., 2013. Structural Geology Algorithms: Vectors \& Tensors: Cambridge, England, Cambridge University Press, 289 pp.

Amor, K., Hesselbo, S. P., Porcelli, D., Thackrey, S. \& Parnell, J., 2008. A Precambrian proximal ejecta blanket from Scotland. Geology, 36, 4, 303-306. https://doi:10.1130/G24454A.1

Baloga, S. M., Fagents, S. A. \& Mouginis-Mark, P. J., 2005. Emplacement of Martian rampart crater deposits. J. Geophys. Res., 110, E10001, https://doi:10.1029/2004JE002338.

Bastow, I.D., Owens, T.J., Helffrich, G. \& Knapp, J.H., 2007. Spatial and temporal constraints on sources of seismic anisotropy: Evidence from the Scottish highlands. Geophysical Research Letters, 34, L05305.

Beacom, L. E., Anderson, T. B. \& Holdsworth, R. E., 1999. Using basement-hosted clastic dykes as syn-rifting palaeostress indicators: an example from the basal Stoer Group, northwest Scotland. Geol. Mag. 136, 301-310.

Branney, M. J. \& Brown, R. J., 2011. Impactoclastic Density Current Emplacement of Terrestrial Meteorite-Impact Ejecta and the Formation of Dust Pellets and Accretionary Lapilli: Evidence from Stac Fada, Scotland. The Journal of Geology, 119, 3, 275-292.

Branney, M.J. \& Kokelaar, B.P., 2002. Pyroclastic density currents and the sedimentation of ignimbrites. The Geological Society Memoir 27, London, 143 pp. 

lapilli within ground-hugging density currents: evidence from contrasting pyroclastic layers on Tenerife. Geological Society of America Bulletin, 122, 1-2, 305-320.

Bursik, M.I. \& Woods, A.W., 1996. The dynamics and thermodynamics of large ash flows.

Cagnoli, B. \& Tarling, D. H., 1997. The reliability of anisotropy of magnetic susceptibility (AMS) data as flow direction indicators in friable base surge and ignimbrite deposits: Italian examples. Journal of Volcanology and Geothermal Research, 75, 309-320.

Cardozo, N. \& Allmendinger, R. W., 2013. Spherical projections with OSXStereonet: Computers \& Geosciences, v. 51, no. 0, p. 193 - 205, doi: 10.1016/j.cageo.2012.07.021

Collins, G.S., Melosh, H.J. \& Marcus, R.A., 2005. Earth Impact Effects Program: A Webbased computer program for calculating the regional environmental consequences of a meteoroid impact on Earth. Meteoritics and Planetary Science, 40, 817-840.

Corfu, F., Heaman, L.M. \& Rogers, G., 1994, Polymetamorphic evolution of the Lewisian complex, NW Scotland, as recorded by U-Pb isotopic compositions of zircon, titanite and rutile: Contributions to Mineralogy and Petrology, 117, 215-228.

Dalziel, I.W.D., 2010. The North-West Highlands memoir: a century-old legacy for understanding Earth before Pangaea. Geological Society, London, Special Publications, 335, 189-205.

Darabi, M. H. \& Piper, J. D. A. 2004. Palaeomagnetism of the (Late Mesoproterozoic) Stoer Group, northwest Scotland: implications for diagenesis, age and relationship to the Grenville Orogeny. Geological Magazine, 141, 1, 15-39. https://doi:10.1017/S0016756803008148

Dobran, F., Neri, A. \& Macedonio, G., 1993. Numerical Simulation of Collapsing Volcanic Columns. Journal of Geophysical Research, 98, B3, 4231-4259.

Drury, S.A., 1978, REE Distributions in a High-Grade Archaean gneiss complex in Scotland: Implications for the genesis of ancient sialic crust. Precambrian Research, 7, 237-257.

Ellwood, B. B. 1982. Estimates of flow direction for calc-alkaline welded tufts and paleomagnetic data reliability from anisotropy of magnetic susceptibility measurements: central San Juan Mountains, southwest Colorado. Earth and Planetary Science Letters, 59, 303-314.

Fowler, M. B., 1986. Large-ion lithophile element characteristics of an amphibolite facies to granulite facies transition at Gruinard Bay, North-west Scotland. Journal of Metamorphic Geology, 4, 345-359.

Friend, C. R. L. \& Kinny, P. D., 1995. New evidence for protolith ages of Lewisian granulites, northwest Scotland. Geology, 23, 1027-1030. https://doi:10.1130/0091-7613 
Friend, C. R. L. \& Kinny, P. D., 2001. A reappraisal of the Lewisian Gneiss Complex: geochronological evidence for its tectonic assembly from disparate terranes in the Proterozoic. Contributions to Mineralogy and Petrology, 142, 198-218.

Friend, C. R. L., Strachan R.A., Kinny, P. D. \& Watt G. R., 2003. Provenance of the Moine Supergroup of NW Scotland: evidence from geochronology of detrital and inherited zircons from (meta)sedimentary rocks, granites and migmatites. Journal of the Geological Society, London, 160, 247-257.

Grady, D. E. \& Kipp, M. E., 1980. Continuum Modelling of Explosive Fracture in Oil Shale. International Journal of Rock Mechanics and Mining Science, 17, 147-157.

Gault, D.E. \& Wedekind, J.A., 1978. Experimental studies of oblique impact. Proceedings of the Lunar and Planetary Science Conference $9^{\text {th }}, 3843-3875$.

Hörz, F., 1965. Untersuchungen an Riesgläsern. Beiträge zur Mineralogie und Petrographie, $11,621-661$.

Hörz, F., Ostertag, R. \& Rainey, D.A., 1983. Bunte Breccia of the Ries - Continuous deposits of large impact craters. Reviews of Geophysics and Space Physics, 21, 1667-1725.

Hrouda, F., 1982. Magnetic anisotropy of rocks and its application in geology and geophysics. Geophysical Surveys, 5, 37-82.

Kenkmann, T. \& Ivanov, B. A., 2006. Target delamination by spallation and ejecta dragging: An example from the Ries crater's periphery. Earth and Planetary Science Letters, 252, 1529.

Kenkmann, T. \& Schönian, F., 2006. Ries and Chicxulub: Impact craters on Earth provide insights for Martian ejecta blankets. Meteoritics and Planetary Science, 41, 10, 1587-1603.

Kieffer, S. W. \& Simonds, C., 1980. The role of volatiles and lithology in the impact process. Reviews of Geophysics and Space Physics, 18, 143-181.

Kinnaird, T. C., Prave, A. R., Kirkland, C. L., Horstwood, M., Parris, R. \& Batchelor, R. A., 2007. The late Mesoproterozoic-early Neoproterozoic tectonostratigraphic evolution of NW Scotland: the Torridonian revisited. Journal of the Geological Society, 164, 541-551 https://doi:10.1144/0016-76492005-096

Kinny, P. D., Friend, R. L. \& Love, J., 2005. Proposal for a terrane-based nomenclature for the Lewisian Gneiss Complex of NW Scotland. Journal of the Geological Society, London, $162,175-186$.

Knight, M. D., Walker, G. P. I., Ellwood, B. B. \& Diehl, J. F., 1986. Stratigraphy, paleomagnetism and magnetic fabric of the toba tuffs: Constraints on the sources and eruptive styles. Journal of Geophysical Research, 91, B10, 10,355-10,382.

Jelinek, W., 1978. Statistical processing of anisotropy of magnetic susceptibility measured on groups of specimens. Studia Geophysica et Geodaetica, 22, 50-62. 

of a pyroclastic density current documented by the anisotropy of magnetic susceptibility (AMS) in the quartz latite ignimbrite of the Pleistocene Monte Cimino volcanic centre (central Italy). Tectonophysics, 466, 64-78.

Lawson, D. E., 1972. Torridonian volcanic sediments. Scottish Journal of Geology, 8, 345362.

Lelpi, A., Ventra, D. \& Ghinassi, M., 2016. Deeply channelled Precambrian rivers: Remote sensing and outcrop evidence from the 1.2 Ga Stoer Group of NW Scotland. Precambrian Research, 281, 291-311

854

Leslie, G., Krabbendam, M., Kimbell, G. S. \& Strachan, R. A., 2010. Regional-scale lateral variation and linkage in ductile thrust architecture: the Oykel Transverse Zone, and mullions, in the Moine Nappe, NW Scotland. Geological Society, London, Special Publications, 335, 359-381, https://doi.org/10.1144/SP335.17

859

Lodders, K. \& Fegley, B., 1998. The planetary scientist's companion. London: Oxford University Press.

Love, G. J., Kinny, P. D. \& Friend, C. R. L., 2004. Timing of magmatism and metamorphism in the Gruinard Bay area of the Lewisian Gneiss Complex: comparisons with the Assynt Terrane and implications for terrane accretion. Contributions to Mineralogy and Petrology, 146, 620-636. https://doi 10.1007/s00410-003-0519-1

869

Melosh, H. J., 1989. Impact cratering: a geologic process. Oxford monographs on geology and geophysics; No. 11., Oxford University Press.

Melosh, H. J., Ryan, E.V. \& Asphaug, E., 1992. Dynamic Fragmentation in Impacts: Hydrocode Simulation of Laboratory Impacts. Journal of Geophysical Research, 97, E9, $14,735-14,759$.

Miyashiro, A., 1994, Metamorphic Petrology. UCL Press, 404 pp

Montenat, C., Barrier, P., Ott d'Estevou, P. \& Hibsch, C., 2007. Seismites: An attempt at critical analysis and classification. Sedimentary Geology, 196, 5-30.

Mouginis-Mark, P.J. \& Garbeil, H., 2007. Crater geometry and ejecta thickness of the Martian impact crater Tooting. Meteoritics and Planetary Science, 42 (9) 1615 - 1625.

Nesbitt, H.W., Markovics, G. \& Price. R.C., 1980. Chemical processes affecting alkalis and alkaline earths during continental weathering. Geochimica et Cosmochimica Acta 44, 16591666.

Ort, M.H., Newkirk, T.T, Vilas, J.F. \& Vazquez,J.A., 2015. Towards the definition of AMS facies in the deposits of pyroclastic density currents. Geological Society, London, Special Publications, 396, 205-226 source vents of ignimbrites: empirical observations. Tectonophysics, 307, 207-218. 
894 Park, R. G., Stewart, A. D. \& Wright, D. T., 2002. The Hebridean terrane. In Trewin, N. H. (ed.) The Geology of Scotland, 4th edn, Geological Society of London, 46-80.

Parnell, J., Mark, D., Fallick, A. E., Boyce, A. \& Thackrey, S., 2011. The age of the Mesoproterozoic Stoer Group sedimentary and impact deposits, NW Scotland. Journal of the Geological Society, 168, 349-358. https://doi: 10.1144/0016-76492010-099

Peach, B. N., Horne, J., Gunn, W., Clough, C. T., Hinxman, L. W. \& Teall, J. J. H., 1907.

Piper, J. D. A. \& Poppleton, T. J., 1991. Palaeomagnetic conglomerate tests on basal Stoer

Potter, D. K. \& Stephenson, A., 1988. Single-domain particles in rocks and magnetic fabric analysis. Geophysical Research Letters, 15, 10, 1097-1100.

Rainbird, R.H., Hamilton, M.A, and Young, G.M., 2001. Detrital zircon geochronology and provenance of the Torridonian, N W Scotland. Journal of the Geological Society, 158, 15-27.

Rees, A. I., 1965. The use of anisotropy of magnetic susceptibility in the estimation of sedimentary fabric. Sedimentology, 4, 257-271.

Rees, A. I. \& Woodall, W. A. 1975. The magnetic fabric of some laboratory-deposited sediments. Earth and Planetary Science Letters, 25, 121-130.

Rollinson, H. R. \& Windley, B. F. 1980. Selective elemental depletion during metamorphism of archaean granulites, Scourie, NW Scotland. Contributions to Mineralogy and Petrology, $72,257-263$.

Rollinson, H. R. \& Fowler, M. B. 1987. The magmatic evolution of the Scourian complex at Gruinard Bay. Geological Society, London, Special Publications, 27; 57-71. https://doi: 10.1144/GSL.SP.1987.027.01.06

Rusnak, G. A. 1957. Orientation of sand grains under conditions of unidirectional fluid flow, 1. Theory and Experiment. The Journal of Geology, 65, 384-409.

Sanders, I. S. \& Johnston, J. D., 1989. The Torridonian Stac Fada Member; an extrusion of fluidised peperite? Transactions of the Royal Society of Edinburgh: Earth Sciences, 80, 1-4.

Simms, M. J., 2015. The Stac Fada impact ejecta deposit and the Lairg Gravity Low: evidence for a buried Precambrian impact crater in Scotland? Proceedings of the Geologists' Association. 126, 6, $742-761$.

Stein, A. M., 1988. Basement controls upon basin development in the Caledonian foreland, NW Scotland. Basin Research, 1, 107-119. 
Stewart, A. D. \& Irving, E., 1974. Palaeomagnetism of Precambrian Sedimentary Rocks from

944 NW Scotland and the Apparent Polar Wandering Path of Laurentia. Geophysical Journal of the Royal Astronomical Society, 37, 51-72.

Stewart, A. D., 1993. Late Proterozoic and Late Palaeozoic movement on the Coigach fault in NW Scotland. Scottish Journal of Geology, 29, 21-28. https://doi: 10.1144/sjg29010021

Stewart, A. D., 2002. The later proterozoic torridonian rocks of Scotland: their sedimentology, geochemistry and origin. Geological Society of London, Memoir 24.

Stoffler, D. \& Grieve, R.A.F., 2007. Impactites. In: Fettes, D. and Desmons, J. (eds) Metamorphic Rocks: A classification and glossary of terms, recommendations of the international union of geological sciences. Cambridge University Press, UK.

Strachan, R. A. and Holdsworth, R. E. 1988. Basement-cover relationships and structure within the Moine rocks of central and southeast Sutherland. Journal of the Geological Society, 145, 23-36.

Tarling, D.H. \& Hrouda, F., 1993. The magnetic anisotropy of rocks. London : Chapman and Hall.

Thomas, I. M., Moyer, T. C. and Wikswo Jr., J. P., 1992. High resolution magnetic susceptibility imaging of geological thin sections: Pilot study of a pyroclastic sample from the Bishop Tuff, California, U.S.A. Geophysical Research Letters 19, 21, 2139-2142.

Torsvik, T. H. \& Sturt, B. A., 1987. On the origin and stability of remanence and the magnetic fabric of the Torridonian Red Beds, NW Scotland. Scottish Journal of Geology, 23, 23-38. https://doi: 10.1144/sjg23010023

Young, G. M., 1999. Some aspects of the geochemistry, provenance and palaeoclimatology of the Torridonian NW Scotland. Journal of the Geological Society, 156, 1097-1111.

Young, G. M., 2002. Stratigraphy and geochemistry of volcanic mass flows in the Stac Fada Member of the Stoer Group, Torridonian, NW Scotland. Transactions of the Royal Society of Edinburgh: Earth Sciences, 93, 1-16.

Weaver, B. L. \& Tarney, J., 1980. Rare earth geochemistry of lewisian granulite-facies gneisses, northwest Scotland: implications for the petrogenesis of the archaean lower Continental crust. Earth and Planetary Science Letters, 51, 279-296.

Weaver, B. L., \& Tarney, J., 1981. Lewisian gneiss geochemistry and Archaean crustal development models. Earth and Planetary Science Letters, 55 (1981) 171-180.

Weaver, B. L. \& Tarney, J., 1983, Elemental depletion in Archaean granulite-facies rocks. In: Atherton MP, Gribble CD (eds) Migmatites, melting and metamorphism. Shiva Publishing, Orpington, pp 250-263 

isochron ages from the Late-Archaean Lewisian Complex of northwestern Scotland: implications for geochronology in polymetamorphic high-grade terrains: Geochimica Cosmochim Acta, 60, 3085-3102.

Wohletz, K. H. \& F. Sheridan, F., 1983. Martian Rampart Crater Ejecta: Experiments and Analysis of Melt-Water Interaction. Icarus, 56, 15-37.

\section{Figure Captions}

Fig. 1. - Location map showing outcrop of the Stoer Group (black), field locations mentioned in the text, terrane boundaries and major faults.

Fig. 2. (a) - Overview of the Stac Fada Member at Stoer. White boxes refer to locations of more detailed photographs in figures $2 \mathrm{c}, 2 \mathrm{~d}$ and $2 \mathrm{e}$. The sandstone rafts are encased in suevite. The tabular bedding of the Stoer group sandstones are in sharp contrast to the massive impactite. (b) Closer view of the impactite injected between bedding planes of the Stoer Group sandstone and pinching out towards the north. The white box shows the area in figure 2c. (c) Impact melt rock (shown between two red arrows) is injected between bedding planes for a distance of 5 metres and in this view the impactite appears to have travelled from a southerly direction, pinching out towards the north (right). The hammer is $33 \mathrm{~cm}$ long. (d) Small buckle fold in the underlying Bay of Stoer Formation sandstones at Stoer. The overlying suevite makes a sharp contact with the sandstones. The orientation of the fold axis is $73^{\circ}$. (e) Large overturned block of sandstone completely enveloped by suevite at Stoer. The dashed white line traces the bedding planes. There are no way-up criteria in the sandstone. The block may also have been rotated on a vertical axis during deposition of the granular density current.

Fig. 3. (a) Basal breccia of Stac Fada Member at Enard Bay, randomly oriented angular and rounded gneiss blocks up to $0.5 \mathrm{~m}$ across resting on Stoer Group sandstone and surrounded by a fine grained matrix. The hammer is $38 \mathrm{~cm}$ in length. (b) Interlocking 'pillow' in the upper part of the basal breccia. The left of the 'pillow' is draped over an earlier deposited one. To the right and beneath the 'pillow' is mixed breccia and melt rich impact rock. The hammer is $38 \mathrm{~cm}$ in length. (c) Fining upward graded sandstone beds in post impact sediments and assumed to have been deposited in a standing body of water. These lay a few metres above the undulating airfall bed at the top of the impactite. (d) Incised square cut channel in the overlying graded bedded sandstone of the Meall Dearg Formation at Enard Bay about $2 \mathrm{~m}$ above the airfall bed of the impactite. The gneiss clasts are matrix-supported. The channel has an orientation of $6^{\circ} \mathrm{N}$. The coin is $21.4 \mathrm{~mm}$ in diameter.

Fig. 4. (a) Overview of the Stac Fada ıvember at Stattic Point. The impacuce is about $8 \mathrm{~m}$ thick at this location. The area in the white box is the upper surface shown in figure 4c. (b) Large pale green, 'bomb' or melt clast at Stattic Point measuring $17 \mathrm{~cm}$ across the long axis and now devitrified. This is about $3 \mathrm{~m}$ above the base of the impactite. (c) complex ogee shaped joints in the eroded upper surface of the impactite. This surface occurs immediately above the small faults and folds as viewed in the section in figures $5 \mathrm{a}$ and $5 \mathrm{~b}$. (d) Decimetre high, sinuous sandstone ridge in Bay of Stoer Formation at Stattic Point immediately beneath the Stac Fada Member suevite. The dashed white line marks the approximate course of the escarpment. The upper surface is thinly brecciated to between $5-30 \mathrm{~mm}$ deep and in places the breccia drapes over the scarp slope (red arrow). These ridges are thought to have been 
1042 formed by soft sediment deformation, or by surface dragging during the passage of the

1043 density current/ejecta curtain. (e) Plan view of the sandstone ridge in figure. 4d, showing the

1044 autoclastic brecciation thought to be a surface seismite caused by the passage of the shock wave. This breccia must have preceded the formation of the escarpment because in places the breccia can be found on the scarp slope (red arrow). The red arrow points to the same location as in fig. $4 \mathrm{~d}$. (f) The base of the impactite and underlying sandstones is often obscured by tide or shingle; however, in this photograph the contact makes two downward steps (red arrows) and a wave rounded sandstone ridge can be traced beneath one of these. (g) Aligned melt clasts in the impactite seen in section at Stattic Point. This weak alignment is only observed in the first metre above the base of the clast poor, impact melt rocks. The white line is parallel to the contact of the Stac Fada Member with the underlying Stoer group sandstone, and the ruler is vertical.

Fig. 5. (a) interpretive sketch based on field observations describing compressional features (thrust fault and stacked decollments) in clast poor, impact melt rocks at Stattic Point. The strike of the thrust faults implies a flow direction from the north-north-west.

(b) Photograph of area sketched in figure 5a, showing location of syn-thrust deformation on the footwall, picked out by fractures in the clast poor impact melt rock. The stacked decollments separated by shear planes on the hanging wall are shown above the thrust plane. At the edge of the photograph to the right is a small normal fault tha does not extend down into the underlying sandstones. Stereonets for the two thrust and one normal fault are shown in figure $12 \mathrm{~g}$.

Fig. 6. (a) Ash pellets at Second Coast (white arrows). This thin, discontinuous band occurs in the topmost $0.5 \mathrm{~m}$ of the impact melt rocks. These ash pellets have a fine grained outer coating and are $2-5 \mathrm{~mm}$ in diameter. The coin is $28.4 \mathrm{~mm}$ in diameter. (b) Photomicrograph of an ash pellet from Enard Bay showing predominantly quartz grains in a fine grained iron oxide matrix and rim. The outward appearance of these ash pellets are similar to the ones found at Second Coast.

Fig. 7. Potassium (\%) vs. Rubidium (ppm) for gneiss clasts found in the Stac Fada clast poor, impact melt rocks at Stoer, Enard Bay and Stattic Point. Data for Gruinard granulite terrane Rollinson and Windley (1980), granulite facies associated with the Assynt terrane and amphibolite facies Fowler (1986). Diagonal lines are K/Rb ratios.

Fig. 8. (a) Frequency dependent susceptibility and (b) dual-frequency of susceptibility measurements, Stattic Point.

Fig. 9. The sphericity of ferromagnetic grains may be determined by comparing the foliation (F) and lineation (L) of the fabric. When F > L then the ellipsoid is oblate (disk shaped) and prolate (rod shaped) when F < L. The Stac Fada clast poor, impact melt rocks shows a predominance for oblate magnetic ellipsoids.

Fig. 10. Lower hemisphere, equal area projection, stereonets for AMS data $(\mathbf{a}-\mathbf{e})$ and buckle fold axis (f) at Stoer. The AMS sample height above the base of the impactite is shown to the upper right of each stereonet. All data is corrected for strike and dip of the Stoer Group strata, which at this location is $197^{\circ} / 24^{\circ} \mathrm{W}$. Note that the compass azimuth given by the AMS data may be parallel or perpendicular to the flow direction. An east-west orientation is inferred because of a convergence of directions from other sites to the west. An alternative north south 
1092 bearing is an option to be considered because of a concurrence with data at Enard Bay in the

1093 vicinity of Soyea Island, Loch Inver and is parallel compressional direction inferred from the 1094 buckle fold. However, data from Stattic Point and Second Coast does not support this and no there is no report of unusual features on the coast by Loch Inver consistent with an impact crater. Data plotted on Stereonet software (Cardozo \& Allmendinger, 2013; Allmendinger et al., 2013).

Fig. 11. Stereonets for AMS data $(\mathbf{a}-\mathbf{e})$ for samples taken at Enard Bay. For key refer to figure 10. An ESE - WNW orientation gives a convergence with other data about $15-20 \mathrm{~km}$ to the WNW of Enard Bay. Both Stoer and Enard Nay show the largest range of orientations in the AMS data. The strike and dip of the Stoer Group sediments at this locality is $197^{\circ} / 13^{\circ}$ W.

Fig. 12. AMS data $(\mathbf{a}-\mathbf{f})$ from Stattic Point. A well defined girdle of $K 1$ and $K 2$ data (figure 12a) indicates a gently dipping plane to the north-west and tightly clustered K3 data is indicative of a dominant magnetic foliation. Flow azimuth orientation of NW-SE. This orientation is also picked out in figures $12 \mathrm{~b}, 12 \mathrm{~d}$ and $12 \mathrm{f}$. (g) two thrust faults dipping north and a normal fault dipping south. The poles of the fault planes are also plotted. These are the small faults illustrated in figures $5 \mathrm{a}$ and $5 \mathrm{~b}$. (h) Stereonet for the dip corrected sandstone ridges illustrated in figures $4 \mathrm{~d}$ and $4 \mathrm{e}$. The local strike and dip of the Stoer group is $198^{\circ} / 26^{\circ} \mathrm{W}$.

Fig. 13. AMS data $(\mathbf{a}-\mathbf{c})$ from Second coast and (d) striation orientations from Loch Thurnaig. The strike and dip of the Stoer group at Second Coast is $214^{\circ} / 20^{\circ} \mathrm{W}$ and $261^{\circ} / 19^{\circ} \mathrm{N}$ at Loch Thurnaig.

Fig. 14. Map showing proposed location of crater (black star) derived from field observations and AMS data. The black crosses show the mean AMS derived orientation at each locality. The AMS data give the sense of direction of motion of the impact density current but this may have been influenced by local topography. Four directions are shown but there is only one point of intersection of the axes from all localities analysed, marked by the black star. The direction of compression of the clast poor, impact melt rocks at Stattic Point (solid red arrow) and striations at Loch Thurnaig (dashed green arrows) are also plotted. The pie charts show the proportion of clasts from the Assynt and Gruinard terranes at each of the three locations where the Stac Fada was analysed, based upon clast petrology and geochemistry. The Assynt and Gruinard terranes are separated by the Strathan Line. 


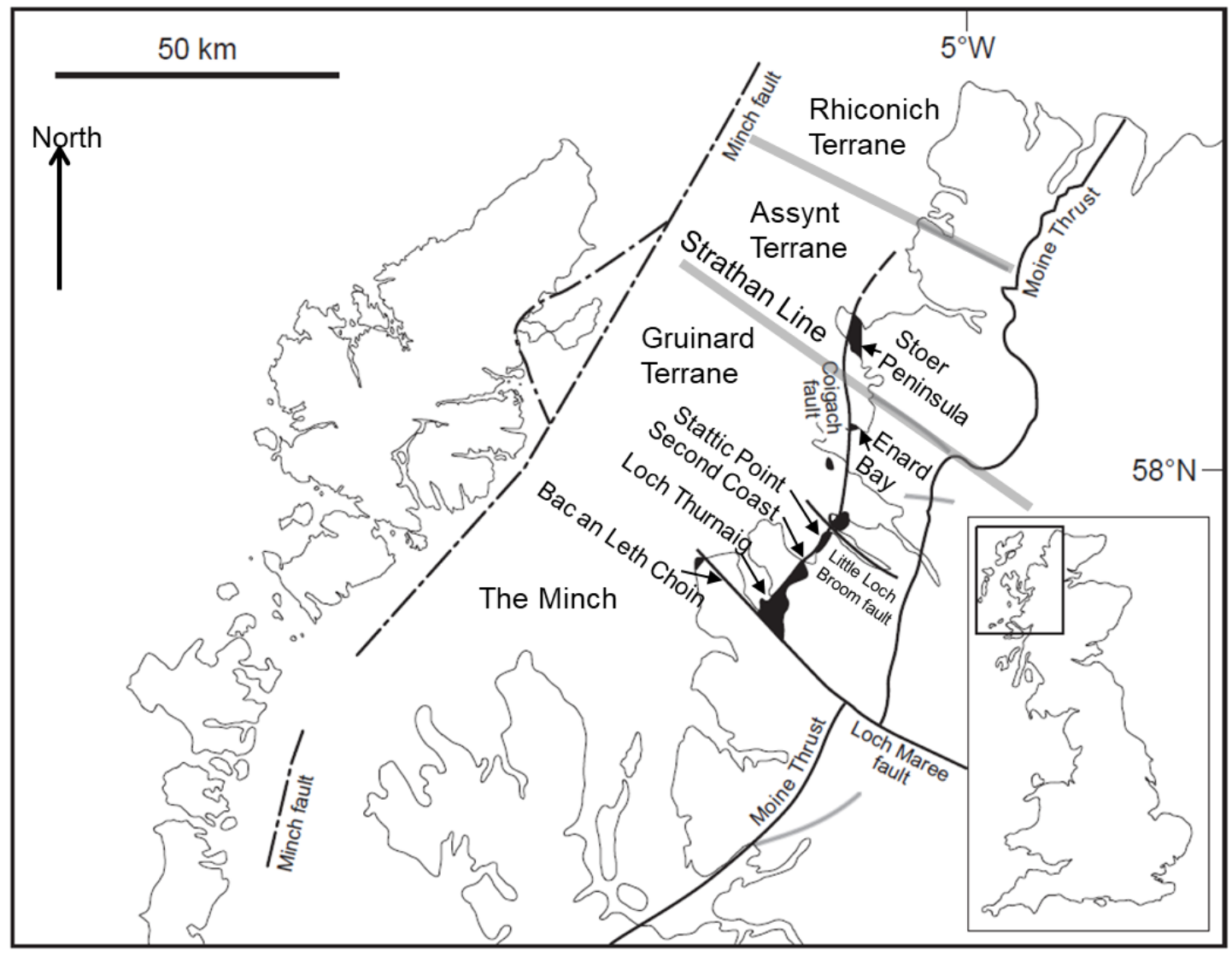



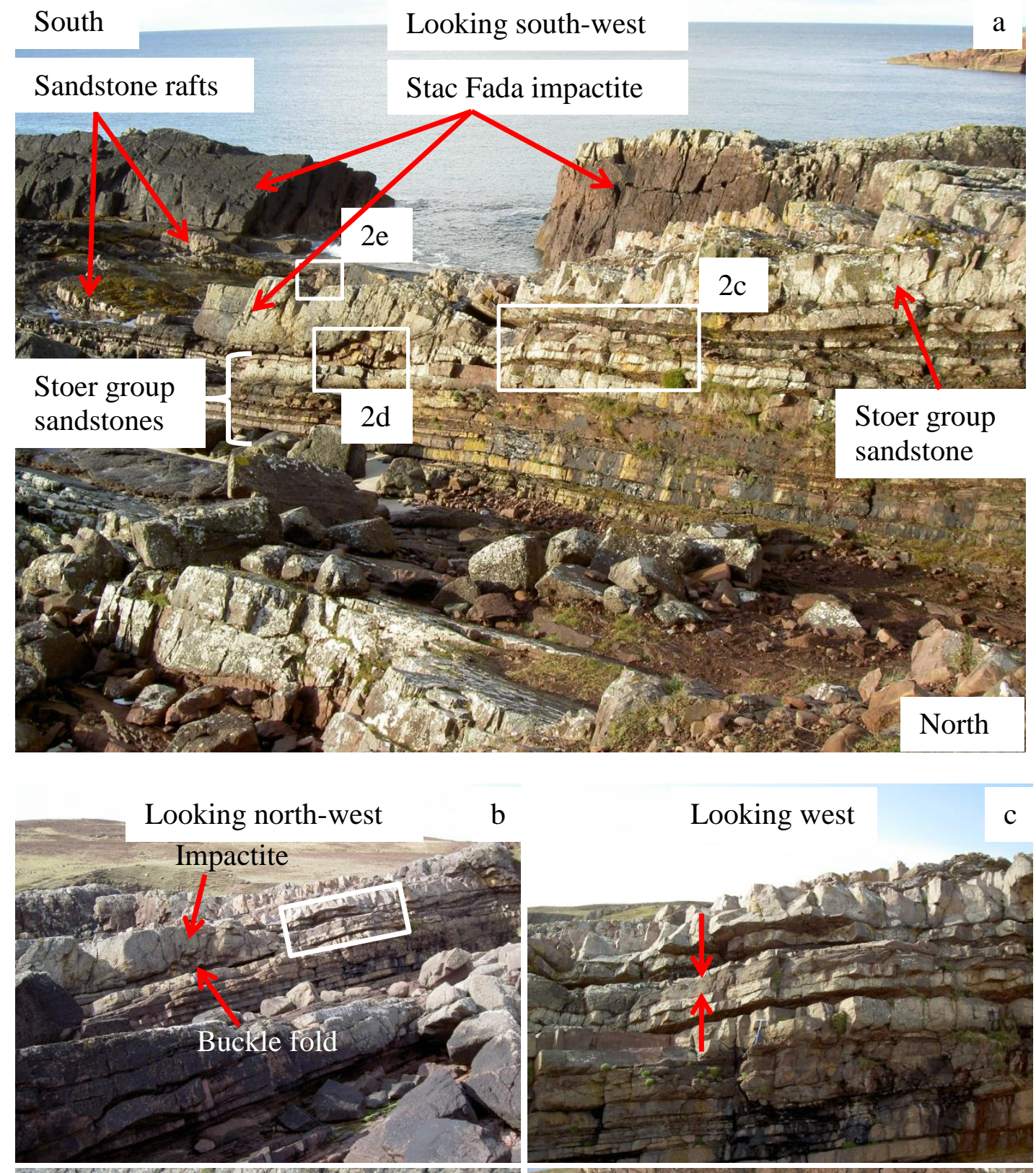

booking west c
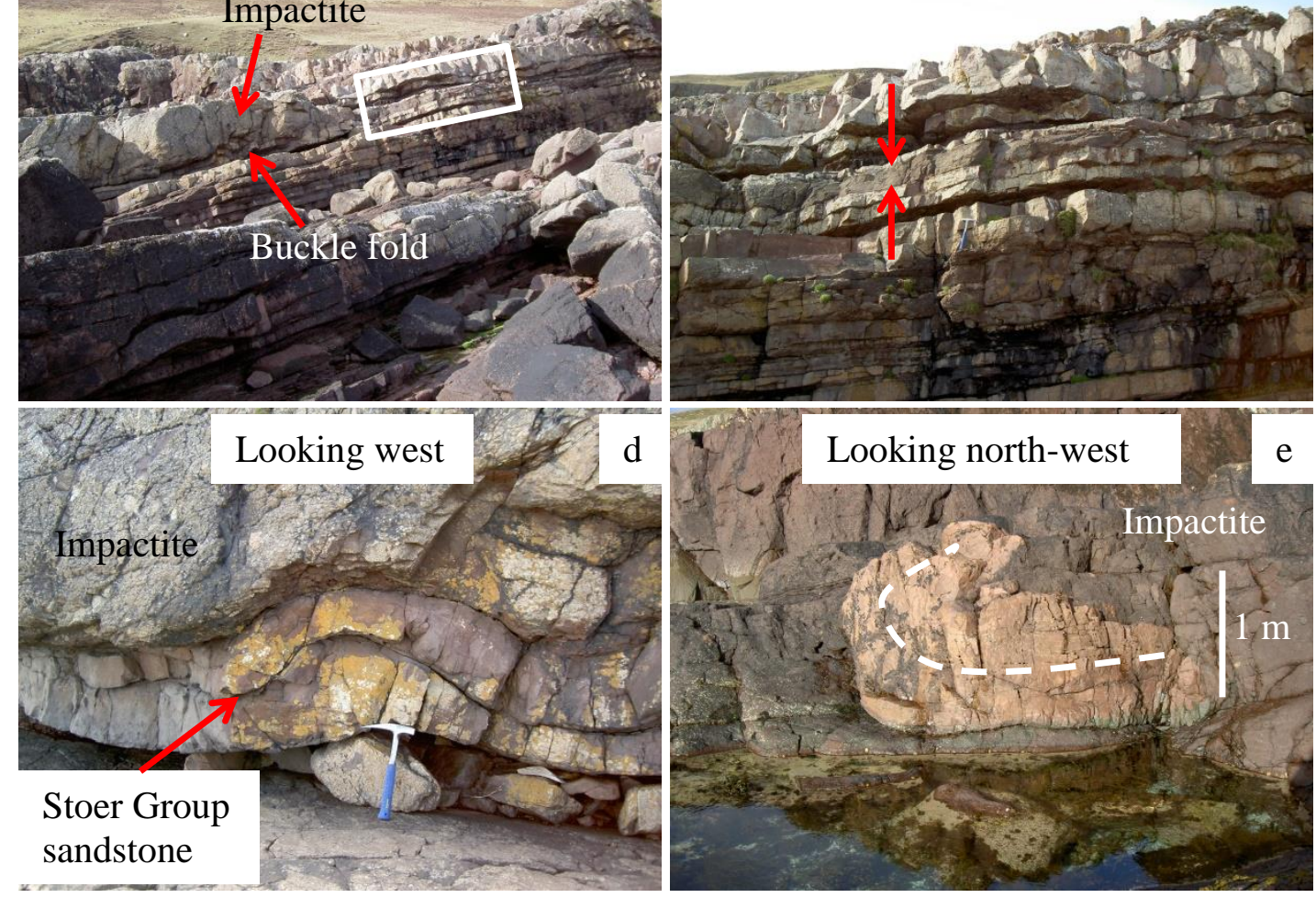

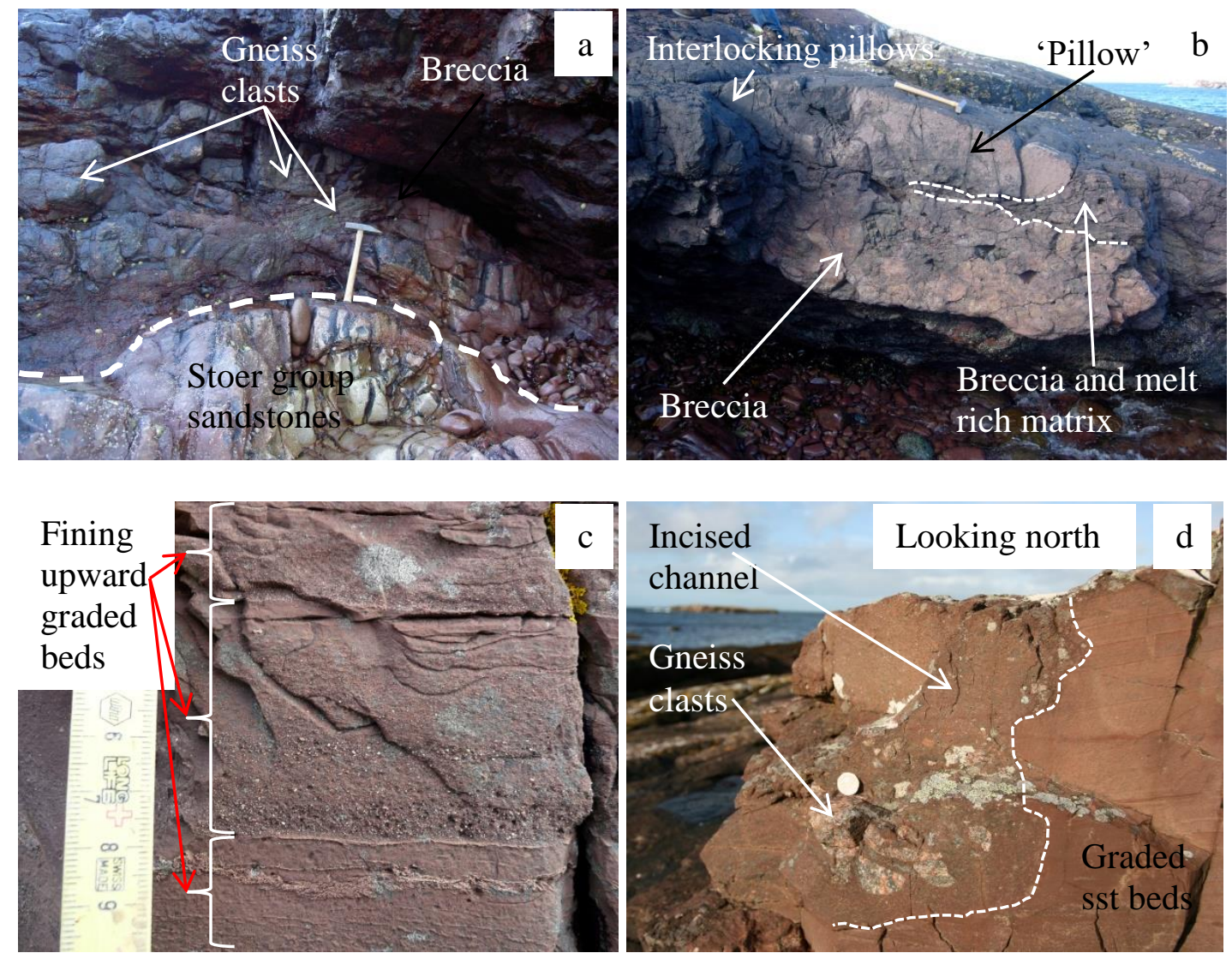

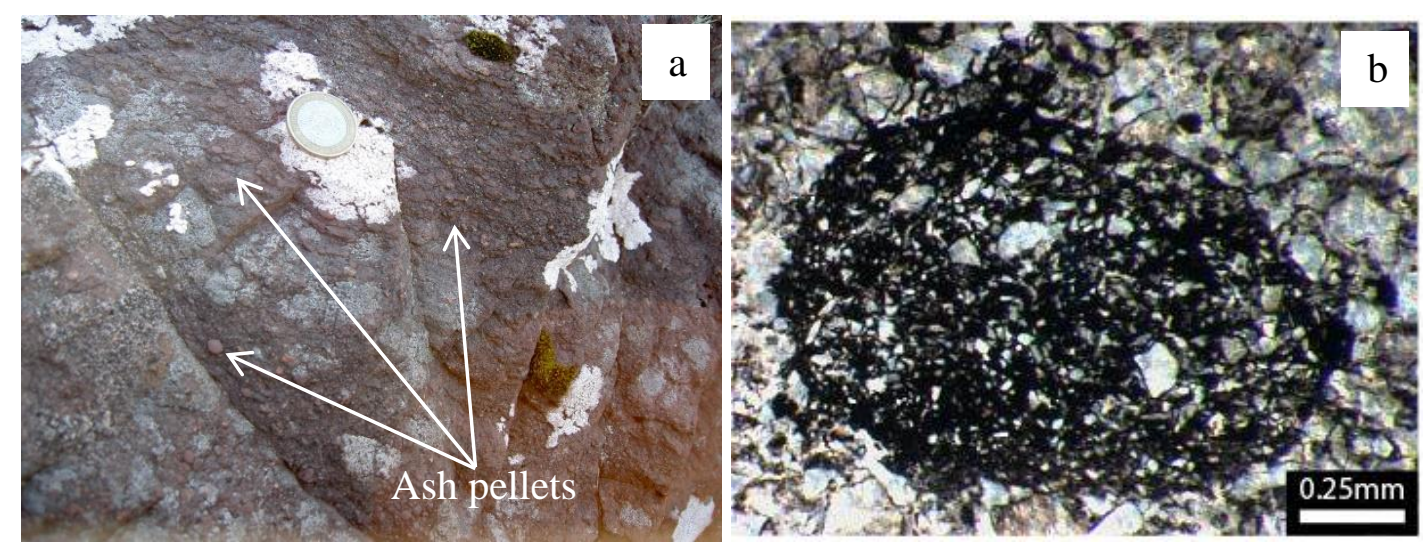


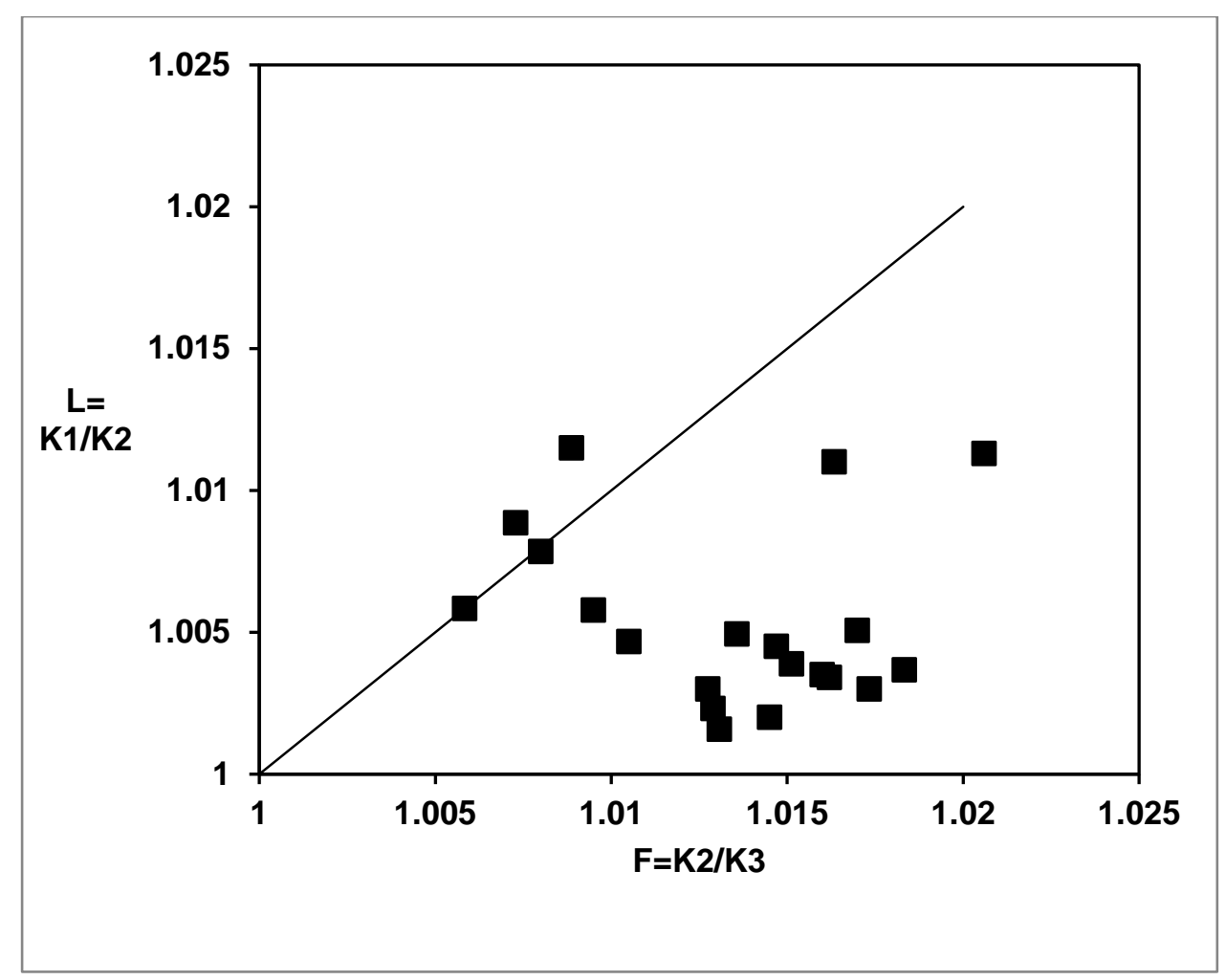




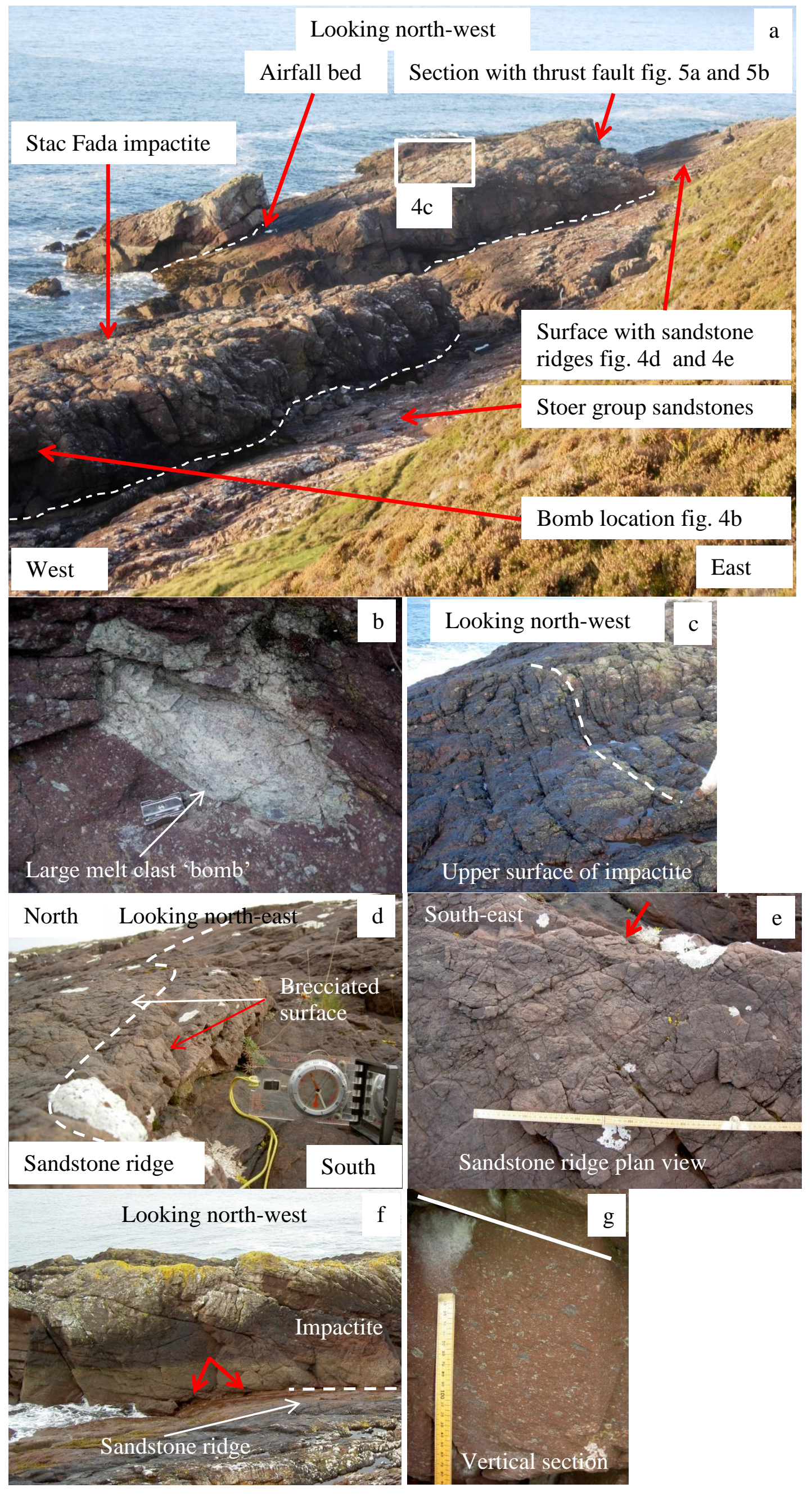


South

-8
-7
-6
-5
-4
-3
-2
-1
0

Probable thrust (strike $081^{\circ}$ dip $59^{\circ} \mathrm{N}$ )

Granule-conglomerate truncating

deformation structures in suevite

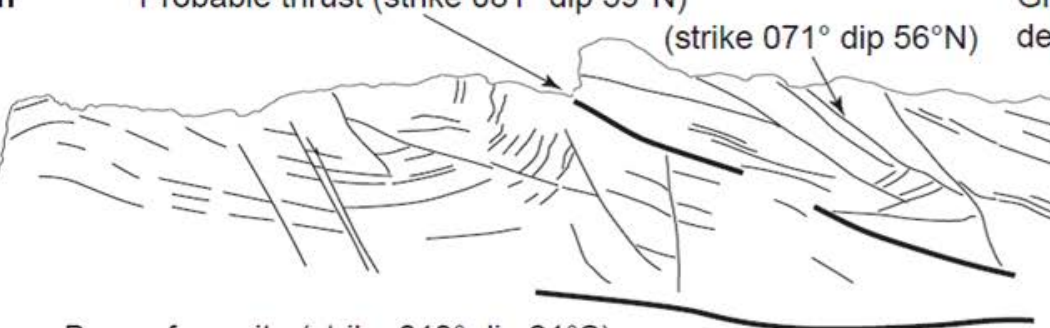

Base of suevite (strike $013^{\circ}$ dip $21^{\circ} \mathrm{S}$ )

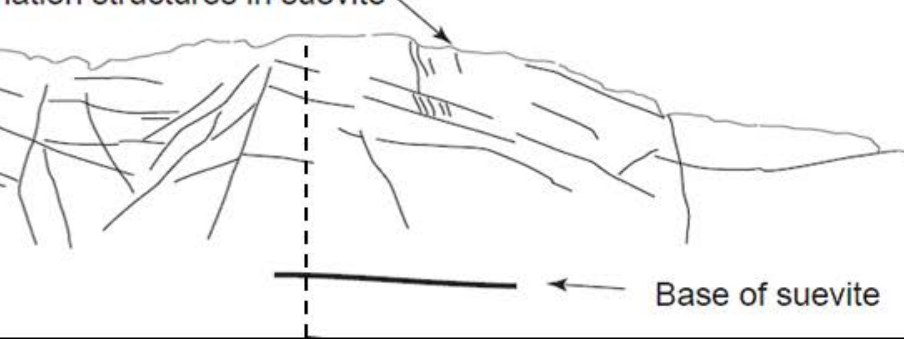

\section{Looking West}

Syn-thrust fold deformation

\section{Stacked decollments}

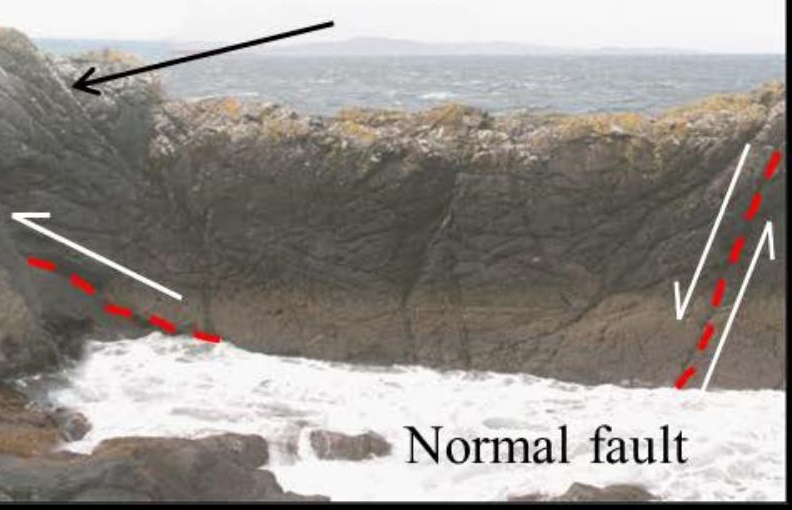




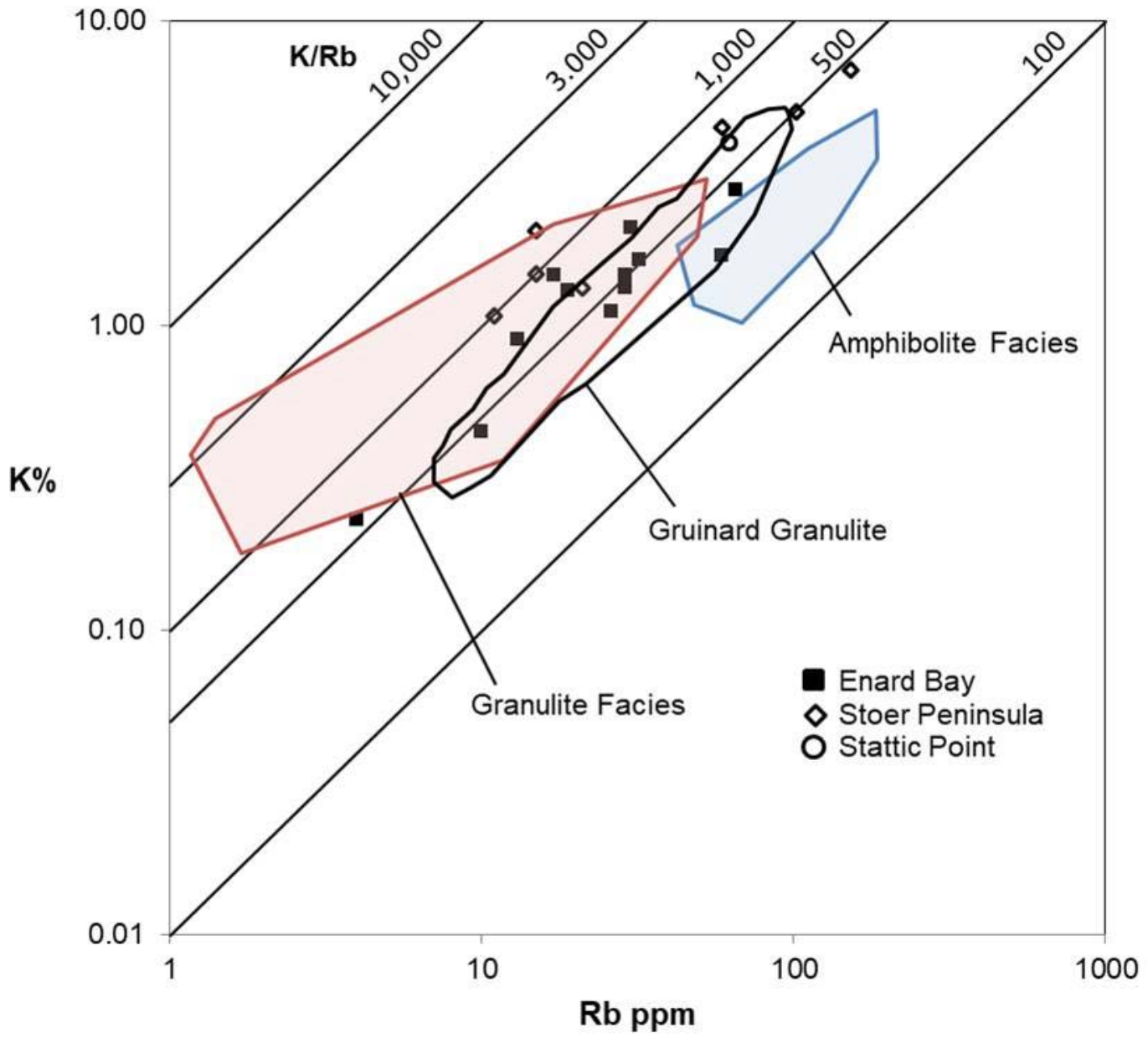


Frequency Dependent Susceptibility

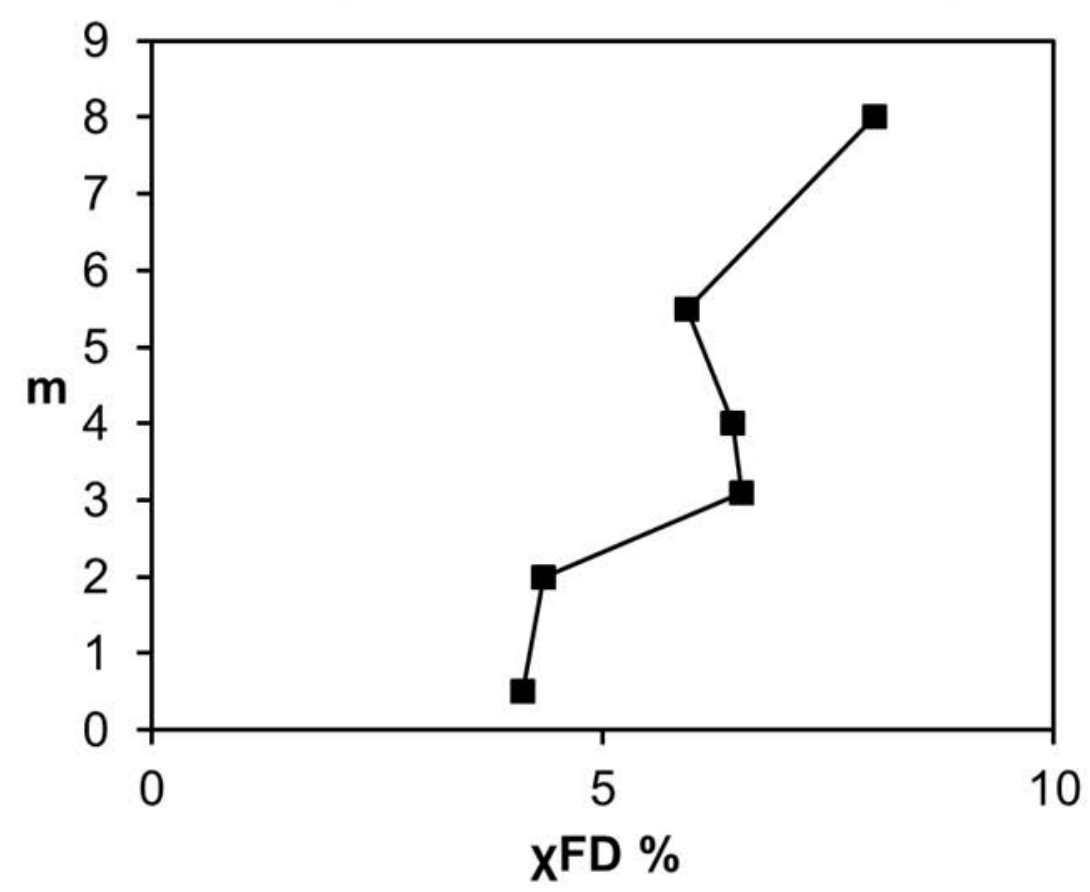

Dual Frequency Suceptibility -

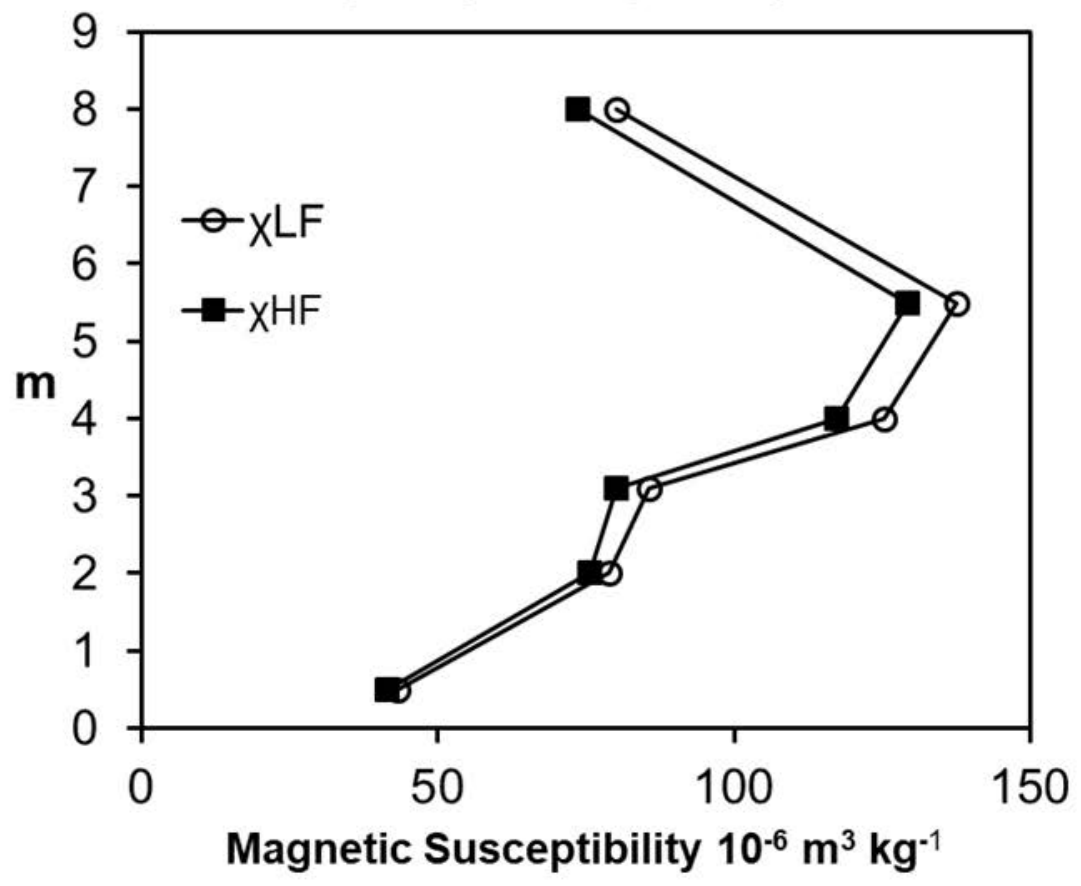




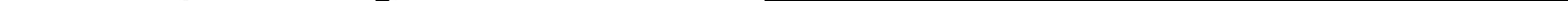




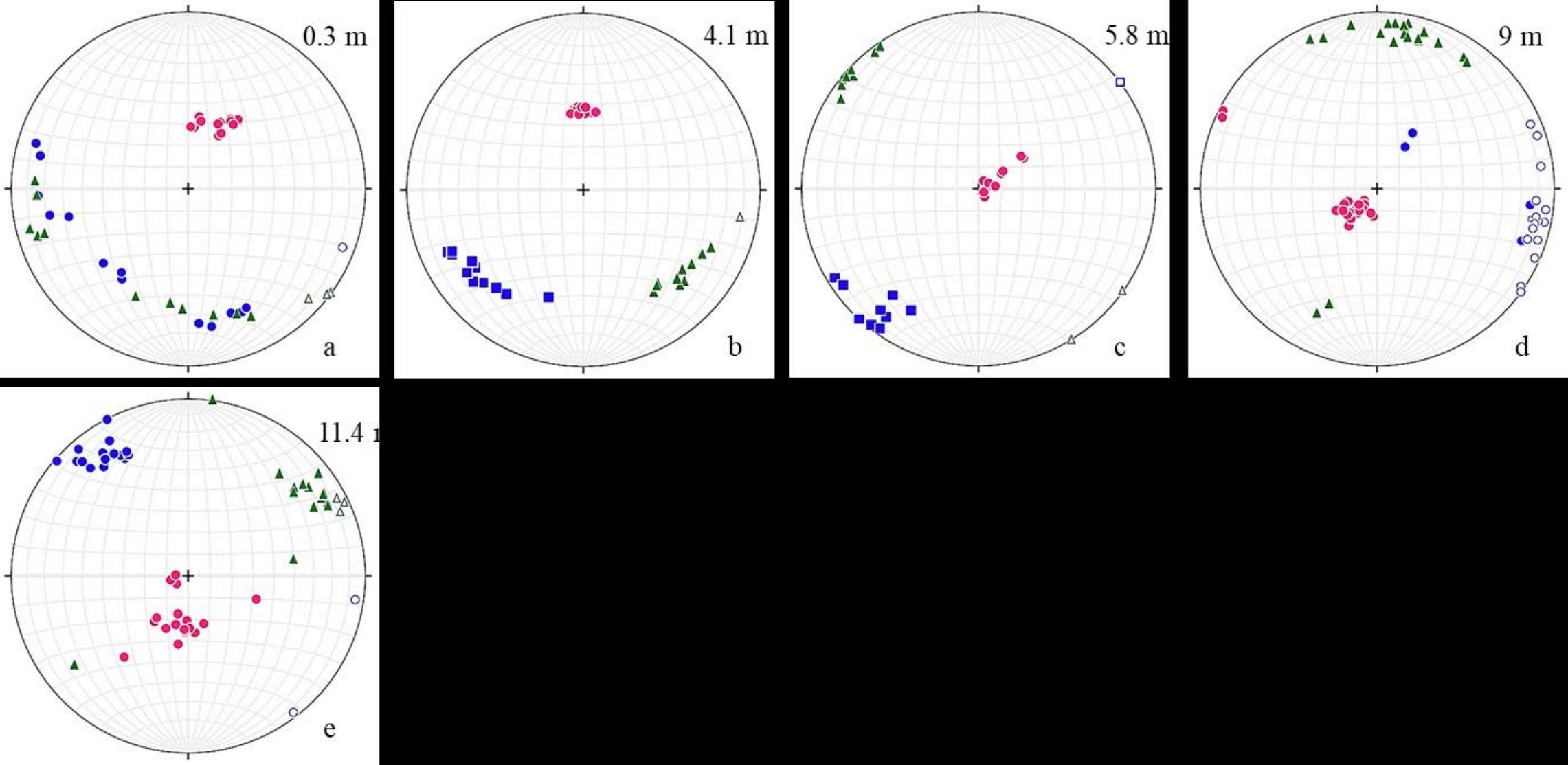




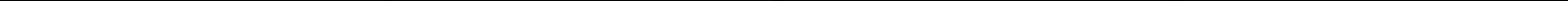


Table 1. Geochemistry for basement clasts extracted from Stac Fada Member at Enard Bay

\begin{tabular}{|c|c|c|c|c|c|c|c|c|c|c|c|c|c|}
\hline Wt.\% & EB201 & EB202 & EB203 & EB204 & EB205 & EB206 & EB207 & EB208 & EB209 & EB210 & EB211 & EB212 & EB213 \\
\hline $\mathrm{TiO}_{2}$ & 0.48 & 0.02 & 0.45 & 0.28 & 0.88 & 0.21 & 1 & 0.45 & 0.52 & 0.28 & 0.46 & 0.03 & 0.16 \\
\hline $\mathrm{Al}_{2} \mathrm{O}_{3}$ & 11.1 & 12.56 & 13.94 & 11.49 & 17.4 & 16.03 & 12.74 & 17.91 & 15.98 & 16.56 & 14.14 & 25.73 & 15.24 \\
\hline $\mathrm{Fe}_{2} \mathrm{O}_{3}^{\top}$ & 5.58 & 0.67 & 3.88 & 1.62 & 7.34 & 1.43 & 18.18 & 4.03 & 2.96 & 1.74 & 6.86 & 3.18 & 2.69 \\
\hline $\mathrm{MgO}$ & 1.18 & 0.25 & 2.46 & 0.49 & 4.15 & 0.67 & 1.19 & 1.17 & 1.52 & 1.21 & 1.18 & 0.19 & 1.79 \\
\hline $\mathrm{CaO}$ & 1.31 & 1331 & 1.13 & 1.51 & 1.81 & 1.93 & 0.8 & 1.04 & 2.27 & 1.78 & 0.99 & 11.31 & 1.37 \\
\hline $\mathrm{Na}_{2} \mathrm{O}$ & 5.29 & 5.78 & 5.18 & 4.34 & 4.53 & 6.02 & 5.54 & 11.72 & 7.41 & 6.2 & 8.25 & 4.43 & 5.44 \\
\hline $\mathrm{K}_{2} \mathrm{O}$ & 0.85 & 0.9 & 1.47 & 1.46 & 2.78 & 2.1 & 1.33 & 0.23 & 1.11 & 1.69 & 0.45 & 1.3 & 1.64 \\
\hline \multicolumn{14}{|l|}{$\mu g g^{-1}$} \\
\hline $\mathrm{Cr}$ & 66 & 23 & 50 & 5 & 156 & 20 & 25 & 105 & 81 & 13 & 193 & 4 & 15 \\
\hline $\mathrm{Ni}$ & 56 & 4 & 78 & 42 & 86 & 9 & 67 & 141 & 78 & 31 & 255 & 1 & 126 \\
\hline $\mathrm{Cu}$ & 7 & 13 & 21 & 14 & 15 & 13 & 12 & 6 & 12 & 30 & 14 & 5 & 10 \\
\hline $\mathrm{Zn}$ & 33 & 31 & 63 & 2 & 123 & 88 & 37 & 31 & 74 & 37 & 40 & 18 & 48 \\
\hline $\mathrm{Rb}$ & 19 & 13 & 29 & 17 & 65 & 30 & 29 & 4 & 26 & 59 & 10 & 19 & 32 \\
\hline $\mathrm{Sr}$ & 202 & 237 & 244 & 347 & 214 & 347 & 379 & 220 & 1034 & 409 & 241 & 425 & 235 \\
\hline $\mathrm{Ba}$ & 143 & 215 & 259 & 792 & 421 & 1243 & 532 & 91 & 518 & 631 & 129 & 335 & 275 \\
\hline $\mathrm{Zr}$ & 64 & 9 & 30 & 10 & 13 & 13 & 5 & 67 & 217 & 31 & 118 & 7 & 3 \\
\hline $\mathrm{Nb}$ & 4.1 & 0.1 & 3.2 & 1.6 & 5.3 & 1.2 & 1.6 & 2.7 & 5.1 & 0.8 & 4.1 & 0.2 & 1.1 \\
\hline Th & 8.6 & 0.1 & 0.5 & 0.0 & 0.1 & 0.0 & 0.5 & 4.7 & 57.5 & 0.4 & 10.7 & 0.1 & 0.1 \\
\hline U & 1.2 & 0.1 & 0.6 & 0.1 & 0.8 & 0.1 & 1 & 1.3 & 2.1 & 0.4 & 1.5 & 0.4 & 0.6 \\
\hline $\mathrm{Hf}$ & 1.8 & 0.3 & 0.8 & 0.3 & 0.4 & 0.4 & 0.1 & 1.8 & 5.4 & 0.9 & 3.1 & 0.2 & 0.1 \\
\hline La & 42 & 35 & 48 & 22 & 59 & 27 & 28 & 30 & 87 & 44 & 66 & 35 & 24 \\
\hline $\mathrm{Ce}$ & 79 & 59 & 96 & 38 & 131 & 46 & 46 & 66 & 222 & 59 & 126 & 60 & 47 \\
\hline $\mathrm{Nd}$ & 37 & 19 & 44 & 15 & 71 & 18 & 17 & 35 & 86 & 22 & 50 & 23 & 19 \\
\hline $\mathrm{Sm}$ & 7 & 2 & 7 & 2 & 13 & 2 & 3 & 7 & 13 & 3 & 8 & 3 & 3 \\
\hline Eu & 1.9 & 1.7 & 2.4 & 1.9 & 3.5 & 2.6 & 1.9 & 1.8 & 3.9 & 2.3 & 2.2 & 1.1 & 1.3 \\
\hline $\mathrm{Tb}$ & 0.9 & 0.2 & 0.8 & 0.2 & 1.6 & 0.2 & 0.4 & 1 & 1.3 & 0.3 & 1 & 0.2 & 0.3 \\
\hline $\mathrm{Yb}$ & 2.6 & 0.3 & 1.4 & 0.3 & 2.1 & 0.4 & 0.6 & 2.1 & 2.4 & 0.3 & 2.5 & 0.4 & 0.7 \\
\hline
\end{tabular}


Table 1. cont.

\begin{tabular}{lrrrrrrr}
$\mathrm{Wt} . \%$ & EB214 & EB215 & EB216 & EB217 & EB218 & EB163B & EB158B \\
\hline $\mathrm{TiO}_{2}$ & 0.42 & 0.73 & 0.41 & 0.44 & 0.32 & 0.36 & 0.26 \\
$\mathrm{Al}_{2} \mathrm{O}_{3}$ & 12.92 & 17.36 & 17.93 & 19.13 & 17.74 & 14.7 & 18.54 \\
$\mathrm{Fe}_{2} \mathrm{O}_{3}{ }^{\top}$ & 3.45 & 2.93 & 3.58 & 3.55 & 2.96 & 3.44 & 1.28 \\
$\mathrm{MgO}$ & 0.82 & 1.18 & 0.2 & 1.27 & 1.43 & 2.5 & 0.46 \\
$\mathrm{CaO}$ & 1.47 & 1.67 & 2.43 & 2.81 & 2.72 & 2.27 & 4.32 \\
$\mathrm{Na} \mathrm{O}_{2} \mathrm{O}$ & 6.77 & 6.09 & 11.48 & 7.09 & 6.24 & 5.29 & 6.55 \\
$\mathrm{~K}_{2} \mathrm{O}$ & 0.84 & 3.01 & 0.4 & 1.42 & 1.38 & 0.76 & 0.51 \\
& & & & & & & \\
$\mu \mathrm{g} \mathrm{g}{ }^{-1}$ & & & & & & & \\
$\mathrm{Cr}$ & 85 & 55 & 97 & 10 & 7 & 67 & 17 \\
$\mathrm{Ni}$ & 95 & 22 & 41 & 19 & 54 & 153 & 22 \\
$\mathrm{Cu}$ & 192 & 206 & 7 & 17 & 8 & 19 & 9 \\
$\mathrm{Zn}$ & 34 & 232 & 71 & 42 & 42 & 57 & 18 \\
$\mathrm{Rb}$ & 17 & 77 & 7 & 27 & 28 & 12 & 6 \\
$\mathrm{Sr}$ & 216 & 335 & 609 & 568 & 519 & 308 & 486 \\
$\mathrm{Ba}$ & 205 & 1666 & 105 & 408 & 609 & 228 & 324 \\
$\mathrm{Zr}$ & 61 & 27 & 30 & 13 & 9 & 21 & 33 \\
$\mathrm{Nb}$ & 3.7 & 4.7 & 2 & 1.7 & 1.5 & 2.4 & 2.7 \\
$\mathrm{Th}$ & 9.9 & 0.1 & 0.3 & 0.3 & 0.6 & 1.6 & 0.2 \\
$\mathrm{U}$ & 1.7 & 0.3 & 0.4 & 0.4 & 0.2 & 0.4 & 0.3 \\
$\mathrm{Hf}$ & 1.6 & 0.8 & 1 & 0.5 & 0.2 & 0.5 & 0.9 \\
$\mathrm{La}$ & 106 & 29 & 63 & 52 & 57 & 60 & 52 \\
$\mathrm{Ce}$ & 199 & 49 & 132 & 104 & 95 & 93 & 89 \\
$\mathrm{Nd}$ & 80 & 20 & 70 & 28 & 34 & 44 & 40 \\
$\mathrm{Sm}$ & 11 & 3 & 13 & 3 & 5 & 7 & 6 \\
$\mathrm{Eu}$ & 3 & 3.9 & 3.6 & 3.2 & 2.8 & 2.4 & 2.7 \\
$\mathrm{~Tb}$ & 1.2 & 0.4 & 1.6 & 0.3 & 0.5 & 0.7 & 0.6 \\
$\mathrm{Yb}$ & 1.7 & 0.8 & 2.3 & 1 & 0.7 & 0.9 & 0.3 \\
\hline & & & & & & &
\end{tabular}


Table 2. Geochemistry for basement clasts extracted from Stac Fada Member at Stoer and Stattic Point

\begin{tabular}{|c|c|c|c|c|c|c|c|c|}
\hline Wt.\% & SF200 & SF204A & SF204B & SF204C & SF206 & SF208 & SF209 & SP222 \\
\hline $\mathrm{TiO} 2$ & na & na & na & na & na & na & na & na \\
\hline $\mathrm{Al} 2 \mathrm{O} 3$ & 18 & 16 & 14 & 15 & 17 & 17 & 14 & 16 \\
\hline $\mathrm{Fe}_{2} \mathrm{O}_{3}{ }^{\top}$ & 2 & $<1$ & 2 & 3 & 1 & 1 & 1 & 2 \\
\hline $\mathrm{MgO}$ & 1 & $<1$ & 1 & 1 & $<1$ & 1 & $<1$ & 1 \\
\hline $\mathrm{CaO}$ & 2 & 2 & 2 & 1 & 2 & 1 & 1 & 2 \\
\hline $\mathrm{Na} 2 \mathrm{O}$ & 7 & 8 & 7 & 6 & 7 & 6 & 6 & 6 \\
\hline $\mathrm{K} 2 \mathrm{O}$ & 1 & 1 & 1 & 4 & 2 & 7 & 5 & 4 \\
\hline \multicolumn{9}{|l|}{$\mu g^{-1}$} \\
\hline $\mathrm{Cr}$ & 48 & 4 & 143 & 48 & 4 & 7 & 2 & 15 \\
\hline $\mathrm{Ni}$ & 101 & 25 & 92 & 254 & 24 & 10 & 18 & 39 \\
\hline $\mathrm{Cu}$ & 17 & 13 & 12 & 14 & 16 & 13 & 5 & 13 \\
\hline $\mathrm{Zn}$ & 92 & 68 & 160 & 99 & 78 & 72 & 47 & 82 \\
\hline $\mathrm{Rb}$ & 21 & 15 & 11 & 59 & 15 & 153 & 102 & 62 \\
\hline Sr & 351 & 566 & 421 & 184 & 449 & 615 & 448 & 287 \\
\hline $\mathrm{Ba}$ & 394 & 255 & 559 & 1501 & 711 & 2216 & 1814 & 1188 \\
\hline $\mathrm{Zr}$ & 113 & 15 & 18 & 87 & 12 & 107 & 97 & 35 \\
\hline $\mathrm{Nb}$ & 2 & 0 & 3 & 13 & 1 & 2 & 2 & 3 \\
\hline Th & 0.8 & 1 & 5.5 & 11.4 & 0.7 & 13.1 & 43.4 & 1 \\
\hline$U$ & 0.9 & 0.3 & 0.5 & 0.9 & 0.2 & 1 & 1.6 & 0.5 \\
\hline $\mathrm{Hf}$ & 5 & 1 & 2 & 3 & 1 & 4 & 4 & 2 \\
\hline La & 44 & 16 & 43 & 110 & 29 & 11 & 32 & 53 \\
\hline $\mathrm{Ce}$ & 78 & 28 & 159 & 211 & 44 & 17 & 57 & 72 \\
\hline $\mathrm{Nd}$ & 32 & 8 & 44 & 100 & 12 & 15 & 25 & 22 \\
\hline Sm & 5 & 1 & 8 & 18 & 1 & 3 & 4 & 3 \\
\hline Eu & 2 & 1 & 3 & 7 & 3 & 4 & 4 & 3 \\
\hline $\mathrm{Tb}$ & 0.6 & 0.2 & 0.9 & 2.2 & 0.2 & 0.4 & 0.4 & 0.4 \\
\hline$Y b$ & 0.8 & 0.1 & 1 & 3.6 & 0.2 & 0.6 & 0.5 & 0.5 \\
\hline
\end{tabular}

